九州大学学術情報リポジトリ

Kyushu University Institutional Repository

\title{
A BIOSYSTEMATIC STUDY OF THE GENUS ATHALIA LEACH OF JAPAN (HYMENOPTERA : TENTHREDINIDAE)
}

Abe, Masaki

https://doi.org/10.5109/2508

出版情報: ESAKIA. 26，pp.91-131，1988-01-25. Entomological Laboratory，Faculty of Agriculture， Kyushu University

バージョン :

権利関係 : 


\title{
A BIOSYSTEMATIC STUDY OF THE GENUS $\boldsymbol{A} \boldsymbol{T H} \boldsymbol{A} \boldsymbol{L I A}$ LEACH OF JAPAN (HYMENOPTERA : TENTHREDINIDAE)*
}

\author{
Masaki AB E \\ Entomological Laboratory, Faculty of Agriculture, \\ Kyushu University, Fukuoka 812, Japan
}

\begin{abstract}
The Japanese species of the genus Athalia Leach, 1817 are revised. Seven species and one subspecies, i. e., A. japonica (Klug, 1815), A. infumata (Marlatt, 1898), A. proxima (Klug, 1834), A. rosae ruficornis Jakovlev, 1888, A. kashmirensis Benson, 1932, A. yanoi Takeuchi, 1952, stat. nov. and A. scutellariae Cameron, 1880, are recognized not only from the morphological characters of the adults and larvae including chromosome number but also from the biological knowledge such as host plants, life cycle, natural enemies, distribution, and electrophoretic analysis of the larval hemolymph protein. A. scutellariae is recorded from Japan for the first time. Redescriptions of the adults of all the species in Japan are given. Descriptions of the larvae of all the species except those of A. scutellariae are also given. Larvae of A. kashmirensis and A. yanoi are newly described. Keys to species and subspecies are given both for the adults and larvae.
\end{abstract}

\section{Introduction}

The genus Athalia Leach, 1817 has been known to comprise 73 species and 6 subspecies. It is worldwide in distribution; 34 species and 3 subspecies are known from the Palaearctic Region, 35 species and 3 subspecies from the Ethiopian Region, and 6 species and 1 subspecies from the Oriental Region. Some of them are well- known agricultural pests because they attack cruciferous plants such as cabbages, turnips, radishes and mustards.

Takeuchi (1952) studied the taxonomy of Japanese Athalia and recorded the following 5 species and 6 subspecies : A. japonica, A. rosae japanensis, A. lugens infumuta, A. 1. camtschatica, A. 1. tibialis, A.l.proxima, A. liberta yanoi and A. kashmirensis. Benson (1962) subsequently revised this genus on a world-wide basis and divided it into 8 species-groups including 2 species-complexes. He recognized 5 species and 4 subspecies from Japan : A. japonica, A. rosae nuficornis, A. lugens infumata, A. 1. proxima, A. liberta yanoi and A. kashmirensis. Zombori (1978) later suggested that A. $l$. infumata and A. 1. proxima are junior synonyms of A. l.lugens. Thus, the taxonomy of Japanese Athalia was controversial at that time.

* Contribution from the Entomological Laboratory, Faculty of Agriculture, Kyushu University, Fukuoka (Ser. 3, No. 254). 
In this paper, a taxonomic revision of Japanese Athalia is made. It is based not only on the morphology of adults and larvae including chromosome number but also on certain biological knowledge such as host plants, life history, habits, natural enemies, distribution, and eletrophoretic pattern of larval hemolymph protein. Based on these studies, the Japanese Athalia species recognized are as follows : A. japonica, A. infumata, A. proxima, A. rosae ruficomis, A. kashmirensis, $A$. yanoi and $A$. scutellariae.

The following abbreviations are used for depositories.

BLKU Biological Laboratory, College of General Education, Kyushu University, Fukuoka.

EIHU Entomological Institute, Faculty of Agriculture, Hokkaido University, Sapporo.

ELKU Entomological Laboratory, Faculty of Agriculture, Kyushu Universioy, Fukuoka.

HBLKU Hikosan Biological Laboratory, Faculty of Agriculture, Kyushu University, Soeda, Fukuoka Pref.

IAC Ishikawa Agricultural College, Nonoichi, Ishikawa Pref.

KUK Entomological Laboratory, Faculty of Agriculture, Kobe University, Kobe.

NIAES Laboratory of Insect Systematics, National Institute of Agro-Environmental Sciences, Tsukuba, Ibaraki Pref.

UOP Entomological Laboratory, College of Agriculture, University of Osaka Prefecture, Sakai.

The following abbreviations are also used for the localities where the specimens were collected.

FAH Mt. Haseyama, Amagi, Fukuoka Pref.

FFH Hakozaki, Fukuoka.

FFT Mt. Tachibanayama, Fukuoka.

FMJ Mt. Joyama, Munakata, Fukuoka Pref.

FSH Mt. Hikosan, Soeda, Fukuoka Pref.

HIT Tomakomai, Iburi Prov., Hokkaido.

HKA Asahidake-onsen, Kamikawa Prov., Hokkaido.

HKS Shibecha, Kushiro Prov., Hokkaido.

HKT Tennin-kyo, Kamikawa Prov., Hokkaido.

HRT Toikanbetsu, Rumoi Prov., Hokkaido.

HT A Ashoro, Tokachi Prov., Hokkaido.

KTN Nakanoshima Is., Tokara Isls., Kagoshima Pref.

OIK Kyan-misaki, Itoman, Okinawa Pref.

OKK Mt. Kurodake, Mts. Kuju, Oita Pref.

\section{Acknowledgments}

I express my sincere gratitude to my supervisor Prof. Y. Hirashima (ELKU) for his continuous direction and encouragement, and to Prof. Emer. T. Nishida (Department of Entomology, University of Hawaii), Assoc. Prof. K. Morimoto (ELKU) and Dr. 0. Yata (BLKU) for their critical review of the manuscript. My hearty thanks are also due to Dr. 0. Tadauchi and Dr. C. Okuma (ELKU) for their constant guidance. I am very grateful to Prof. I. Togashi (IAC), Assoc. Prof. T. Naito (KUK), Dr. A. Shinohara (UOP), Prof. T. Saigusa, Assoc. Profs. A. Nakanishi, H. Shima and Dr. Y. Kobayakawa (BLKU) for their encouragement. I extend special thanks to Assoc. Prof. T. Kawarabata (Division of Insect Pathology, Institute of Biological Control, Faculty of Agriculture, Kyushu University) for his guidance on the chromosomal experiments, to Prof. H. Doira and Dr. Y. Banno (Silkworm Genetics Division, Institute of Genetic Resources, Faculty of Agriculture, Kyushu University) for their guidance on the electrophoretic experiments, to Prof. H. Eguchi (Biotron 
Institute, Kyushu University) for his guidance on the rearing experiments, to Prof. S. Masaki (Laboratory of Entomology, Faculty of Agriculture, Hirosaki University), Prof. H. Kitano (Department of Biology, Faculty of Education, Tokyo Gakugei University) and Mr. M. Ôhara (EIHU) for literature, to Prof. T. Tachikawa (Entomological Laboratory, College of Agriculture, Ehime University), Dr. K. Kamijo (Hokkaido Forest Experiment Station, Bibai, Hokkaido), Dr. D. C. Darling (Royal Ontario Museum, Toronto, Canada) and Mr. K. Konishi (NIAES) for identification of the parasitoids from the larvae of Athalia spp., to Dr. K. Baba (Kurokawa, Niigata), Assoc. Prof. M. T. Châjô and Mr. K. Takeno (HBLKU) for giving me a good chance to examine their collections, and to the following persons for the gifts or loans of the specimen used in this work : Prof. Emer. H. Kuroko, Prof. T. Yasuda, Assoc. Prof. S. Moriuchi (UOP) ; Prof. S. Takagi, Assoc. Prof. T. Kumata, Dr. M. Suwa (EIHU) ; Dr. I. Hattori, Dr. H. Hasegawa, Messrs. K. Konishi, S. Yoshimatsu (NIAES) ; Assoc. Prof. J. Emoto (Biological Laboratory, Nanzan University) ; Assoc. Prof. S. lkudome (Biological Laboratory, Kagoshima Women's Junior College) ; Mr. K. Nagasaka (Entomological Laboratory, Faculty of Agriculture, Kyoto University) ; Mr. K. Ôhara (Tokushima Prefectural Museum) ; Dr. K. Maeto (Entomological Laboratory, Forestry and Forest Research Institute, Hokkaido Branch) ; Messrs. H. Takemoto, R. Noda, Ms. K. Kawase (Fukuoka) ; Dr. K. Ogata, Dr. T. Gotô, Messrs. T. Hirowatari, Y. Sawada, M. Rut, Y. Abe, S. Nomura, M. Yoshida, T. Yasunaga (ELKU); Dr. F. C. Thompson (Systematic Entomology Laboratory, USDA, Washington, D. C.) ; Dr. D. M. Wood (Biosystematics Research Center, Agriculture Canada, Ottawa).

\section{Materials and Methods}

1. Morphology

Dried and alcoholic specimens were used for the morphological studies of the adults and larvae. These specimens were sometimes treated with $10 \% \mathrm{KOH}$.

For scanning electron microscopy, larvae were dehydrated in ethanol solutions and critical-pointdried (JCPD-3, JEOL). After gold-coating in an ion sputtering system (T200-SCD, JEOL), the ultrastructures of the specimens were examined under a scanning electron microscope (JSM-T200, JEOL).

All drawings were made with the aid of eyepiece grid under both binocular and standard light microscopes.

The used terminology was after Yuasa (1922) for the morphology of the larvae, Richards (1956) for the general morphology of the adults, Smith $(1969 a, b)$ and Matsuda (1972) for the morphology of the genitalia, and Ohwi (1978) for the host-plants.

2. Chromosomal observation

The species used in this investigation were as follows : A. japonica, A. infumata, A. rosae ruficornis, and A. kashmirensis from the following localities: FFT, FFH, FMJ and FSH.

Eggs with 3 day- or 4 day-old embryo were dissected out from the tissue of host leaves with a forceps discreetly. They were then dissected in hypotonic solution in slides with wells. The yolk of egg was removed as much as possible, and only the embryo was transferred onto a clean slide on which the chromosome preparation was made. The chromosome preparations were made using an air-drying method and then stained with fleshly-prepared Giemsa solution according to the method of Imai et al. (1977).

3. Electrophoretic analysis of the larval hemolymph protein

The species used in this investigation are as follows : A. japonica (from FFT ; FMJ ; FSH ; HTA), A. rosae ruficornis (FFT ; HKS), A. infumata (FFT ; FMJ; HRT), A. kashmirensis (FFH ; 
FFT) and A. yanoi (HKA). About 40-50 samples of the hemolymph for each species were prepared from each female larva of the 5th instar.

Larval hemolymph was forced out from the prolegs pierced with a forceps and was collected with disposable pipettes. Special attention was paid during this procedure to prevent the contamination of the hemolymph by digestive juices of the alimentary canal. The hemolymph was then kept at $-20^{\circ} \mathrm{C}$.

Electrophoresis was carried out on $1 \mathrm{~mm}$-thick slab gels of $6.5 \%$ polyacrylamide with $200 \mathrm{mM}$ Tris-Glicine buffer ( $\mathrm{pH} \mathrm{8.6)}$ at a constant current of $20 \mathrm{~mA}$ at $5^{\circ} \mathrm{C}$ for $2.5 \mathrm{hrs}$. according to the method of Davis (1964).

Some of these gels were stained with a solution of $0.04 \%(w / v)$ Coomassie Brilliant Blue G-250 overnight, destained in $7 \%(\mathrm{w} / \mathrm{v})$ acetic acid and photographed. In order to estimate the relative concentration of each band, the stained gels were scanned using Toyo Densitorol Digital DMU-33C.

Other gels used for testing amylase activity were immersed in the reaction mixture containing $0.75 \%$ soluble starch in $50 \mathrm{mMT}$ ris- $\mathrm{HCl}$ buffer $\left(\mathrm{pH} 7.0\right.$ ) added to $3 \mathrm{mMCaCl}_{2}$ at $37^{\circ} \mathrm{C}$ for 45 minutes and stained by immersion in a solution of $0.01[\mathrm{~N}] \mathrm{I}_{2}-\mathrm{KI}$.

4. Biological observations

The used methods are given in the respective sections under "Biology".

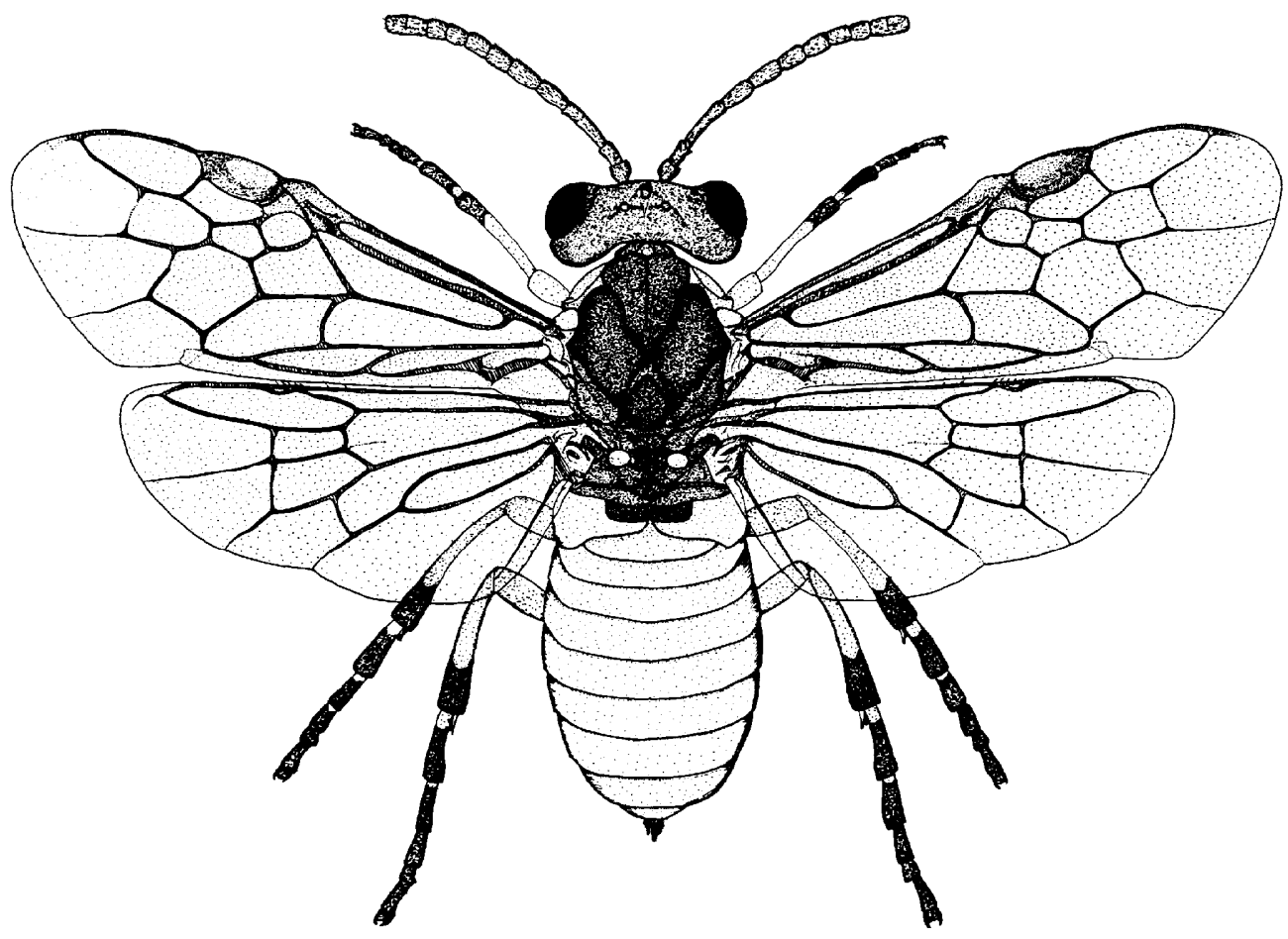

Fig. 1. Athalia yanoi, female. 

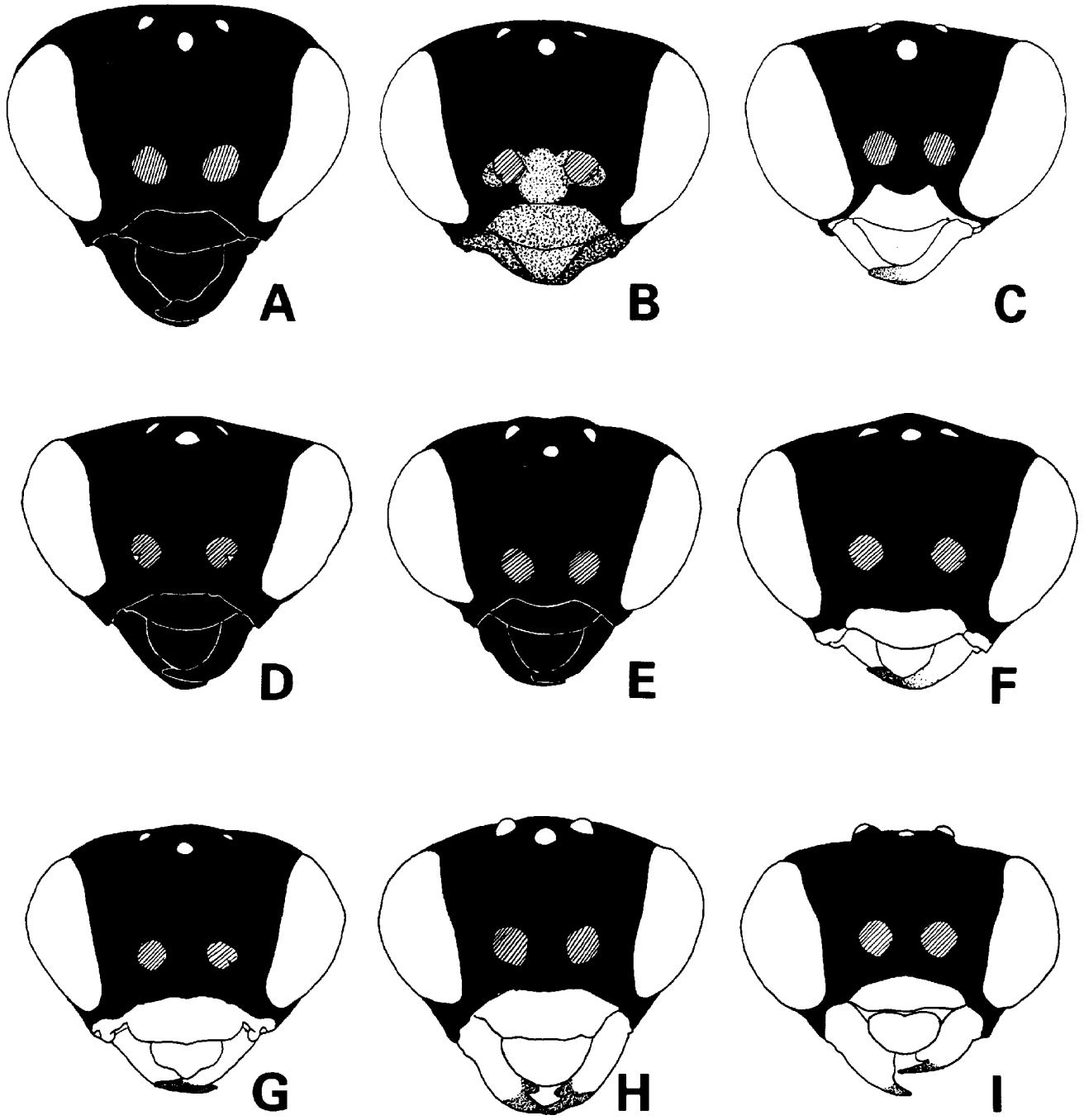

Fig. 2. Color patterns of heads in frontal view. A-C : $\boldsymbol{A}$. japonica, D: $\boldsymbol{A}$. infumata, E: $\boldsymbol{A}$. proxima, F : A. rosae nuficornis, G : A. kashmirensis, H: A. yanoi, I : A. scutellariae — A : spring form, female, B : autumn form, female, C : male, D-I : female.

\section{General M orphology}

1. Adult

General morphology of adults in the Athaliini was reported in detail by Benson (1962). In this paper, emphasis was on the coloration, tarsal claw, clypeus, female hypopygium, saw, and male genitalia, which are important taxonomic characters for the Japanese species. 

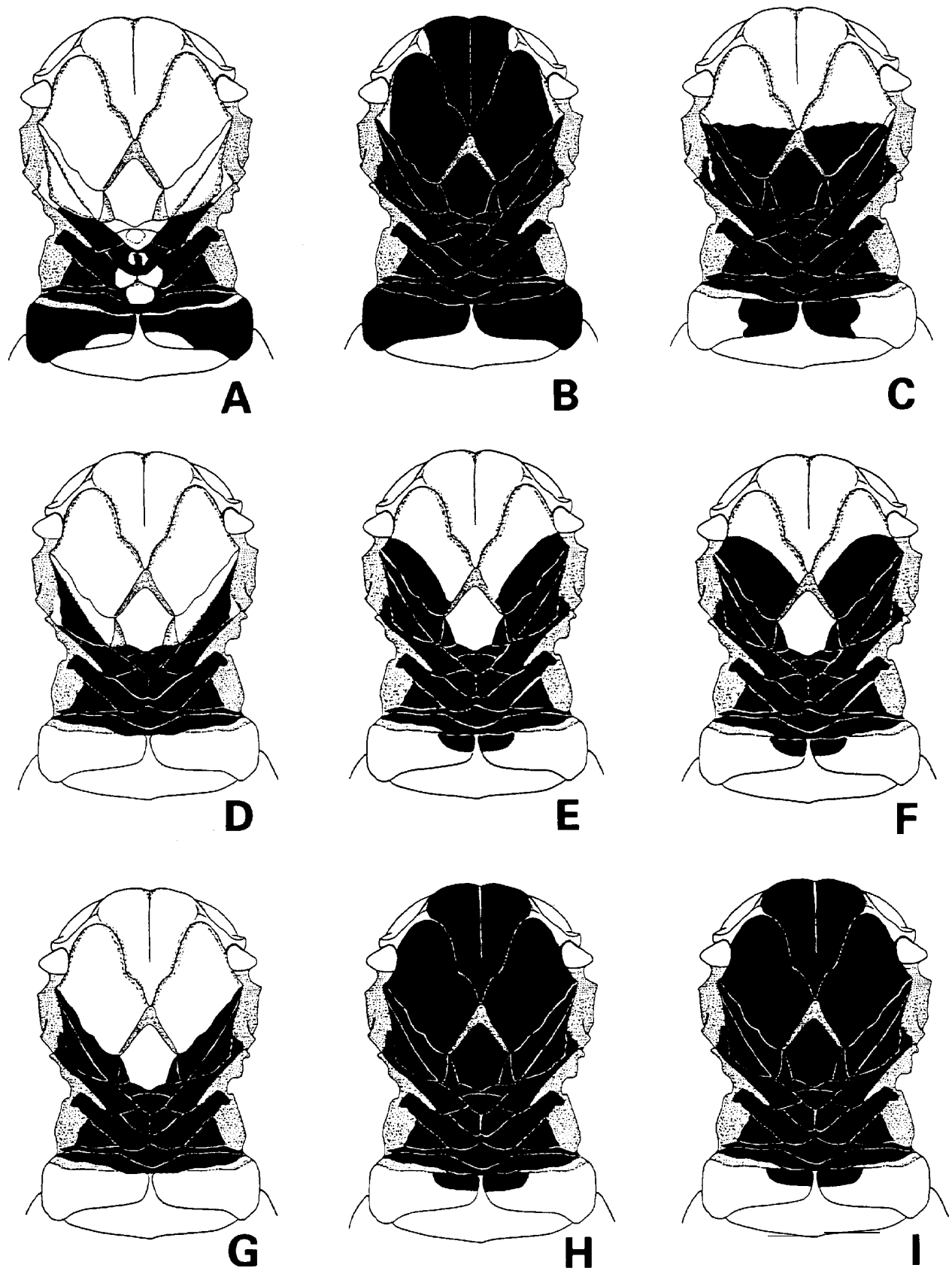

Fig. 3. Color patterns of female thoraces in dorsal view. A : A. japonica, B-C : A. infumata, D : A. proxima, E-F : A. rosae ruficornis, G: A. kashmirensis, H : A. yanoi, I : A. scutellariae. 


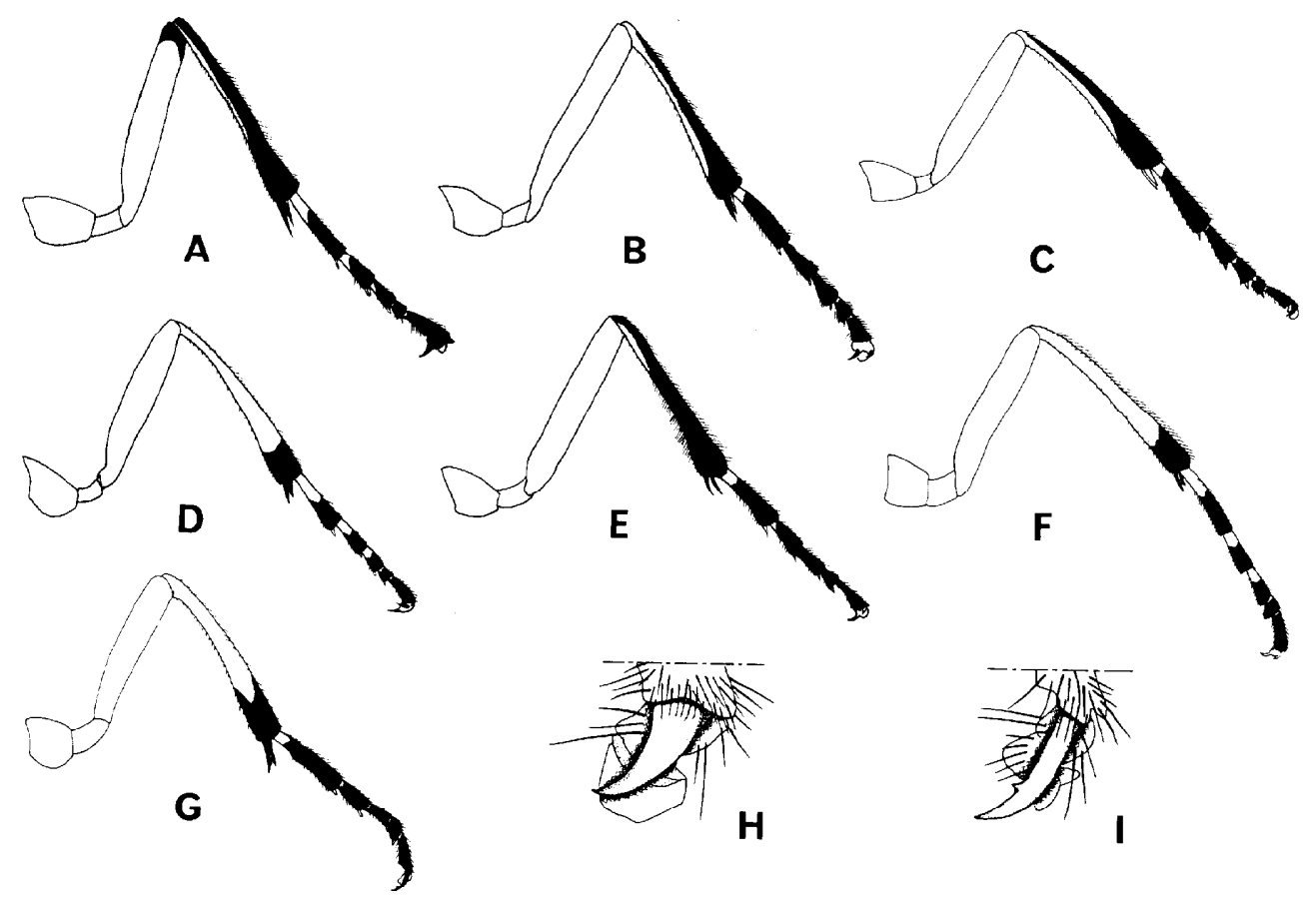

Fig. 4. Color patterns of female hind legs (A-G) and tarsal claws in lateral view (H-I). A \& $H: A$. japonica, B : A. infumata, C : A. proxima, D:A. rosae ruficornis, E: A. kashmirensis, F: A. yanoi, G \& I : A. scutellariae.

\section{Coloration (Figs. $2 ; 3 ; 4$, A-G)}

The basic coloration in Athalia is as follows : head and thorax black, abdomen yellow, and legs yellow with black rings at each joint. The coloration is species-specific, except that the thoracic coloration of $\mathbf{A}$. infumata and $\mathbf{A}$. rosae ruficornis are variable as shown in Fig. 3, B-C and E-F.

Tarsal claw (Fig. 4, H-I)

The structure of tarsal claw is an important character that distinguishes the scutellariae group from the others (Benson, 1962). In fact, only A. scutellariae has an inner tooth in addition to an end tooth on each tarsal claw.

Clypeus (Fig. 2)

The clypeus is the most obvious structure and therefore the most useful character for distinguishing the species-groups of Athalia. The front margin of clypeus is slightly convex and rounded in $\mathbf{A}$. japonica, A. infumata, A. proxima and A. rosae ruficornis, but is truncated with angled sides in $\mathbf{A}$. kaskmirensis and $\mathbf{A}$, yanoi.

Female hypopygium (Fig. 5, left)

The shape of hypopygium is species-specific. However the shape of this structure of A. japonica, A. kaskmirensis and A. yanoi is similar and that of A. infumata is like A. proxima.

Saw (Fig. 5, right)

The shape of female saw is characteristic. All species, except $\mathbf{A}$. infumata and $\mathbf{A}$. proxima, are distinguishable by the shape of the 8 th-10th teeth on the saw.

M ale genitalia (Fig. 6)

The male genitalia, except for penis-valves, have generally been disregarded in the past. But 
A

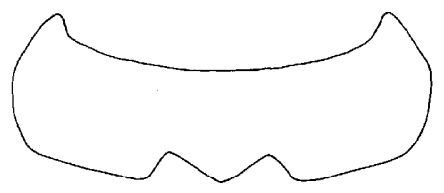

B

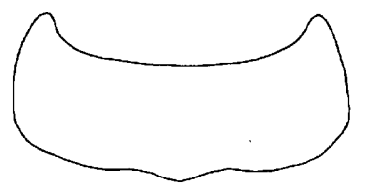

C

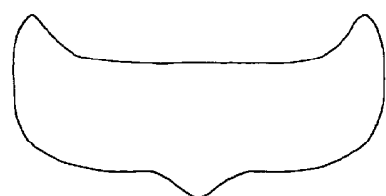

D

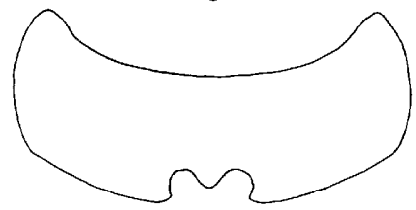

E

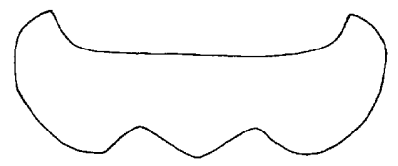

$\mathbf{F}$

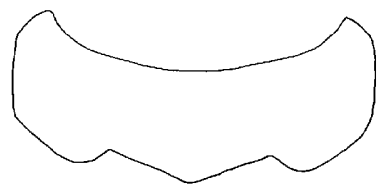

G

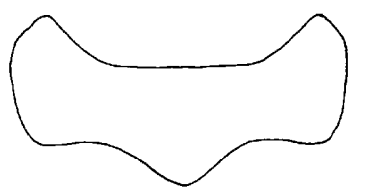

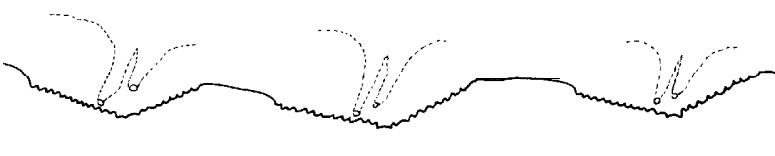
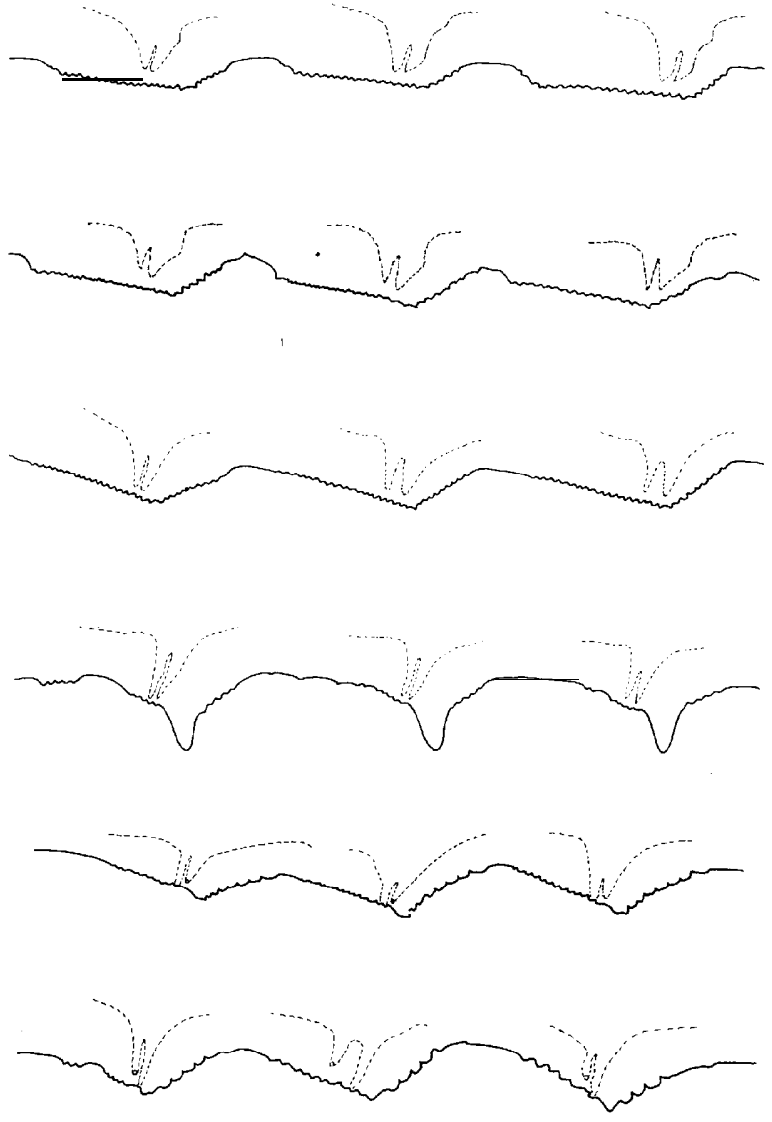

Fig. 5. Female hypopygia (left) and 8th-10th teeth from apex of saw (right). A : A. japonica, B : A. infumata, C:A. proxima, D : A. rosae ruficornis, E: A. kashmirensis, F:A. yanoi, G:A. scutellariae.

some significant differences among species are apparent in the gonostylus, digitus and cuspis, as well as in the penis-valves. Some species of Athalia additionally have a pair of baggy sclerotized processes on the internal portion of the gonocoxite (Fig. 6, A, b). These processes are of great value in distinguishing species and species-groups in Athalia.

A. kashmirensis is similar to A. yanoi in the shape of digitus and cuspis, but the former is different from the latter by the baggy process on the gonocoxite. A. infumata is also similar to A. proxima in terms of the forms of the digitus and cuspis, but is different from the latter in the presence of the baggy process. 

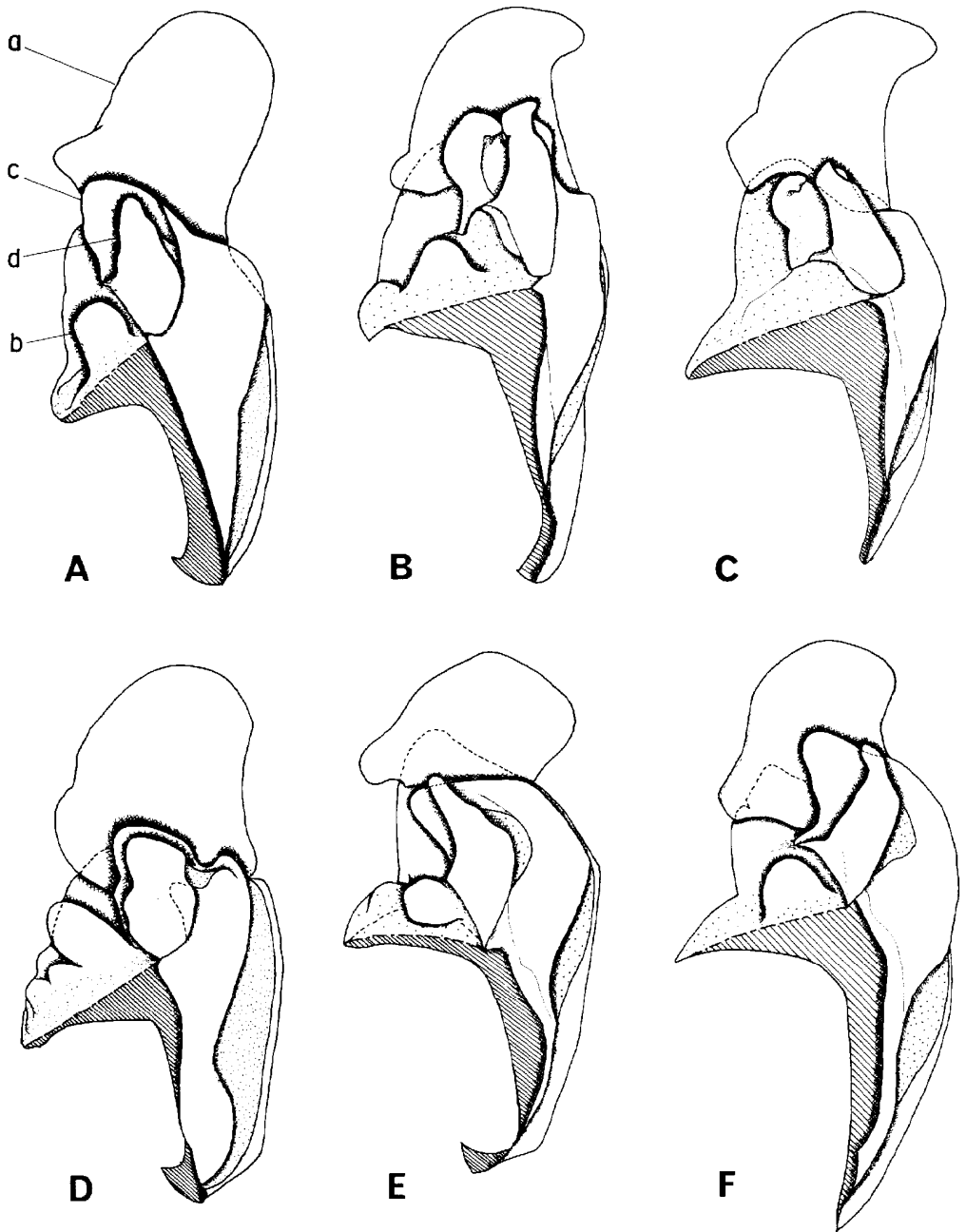

Fig. 6. Male genitalia in inner lateral view. A : A. japonica, B:A. infumata, C:A. proxima, D : A. rosae micomis, E. A. kashmirensis, F: A. yanoi. — a : gonostylus, b : baggy process, c : cuspis, d : digitus.

\section{Larva}

Each Japanese species is characterized mainly by the color pattern and arrangement of the conspicuous fleshy processes on the dorsum (Fig. 7). The distribution of setae may also be different among species. The setae are, however, so small and deeply covered with innumerable small fleshy processes (Fig. 10, A) that it is difficult to use them as taxonomic characters. Generally speaking, the larvae of the Japanese species are very similar morphologically.

\section{Coloration}

Each species is gray in ground color during the 1st-2nd instars, but develops a specific coloration 

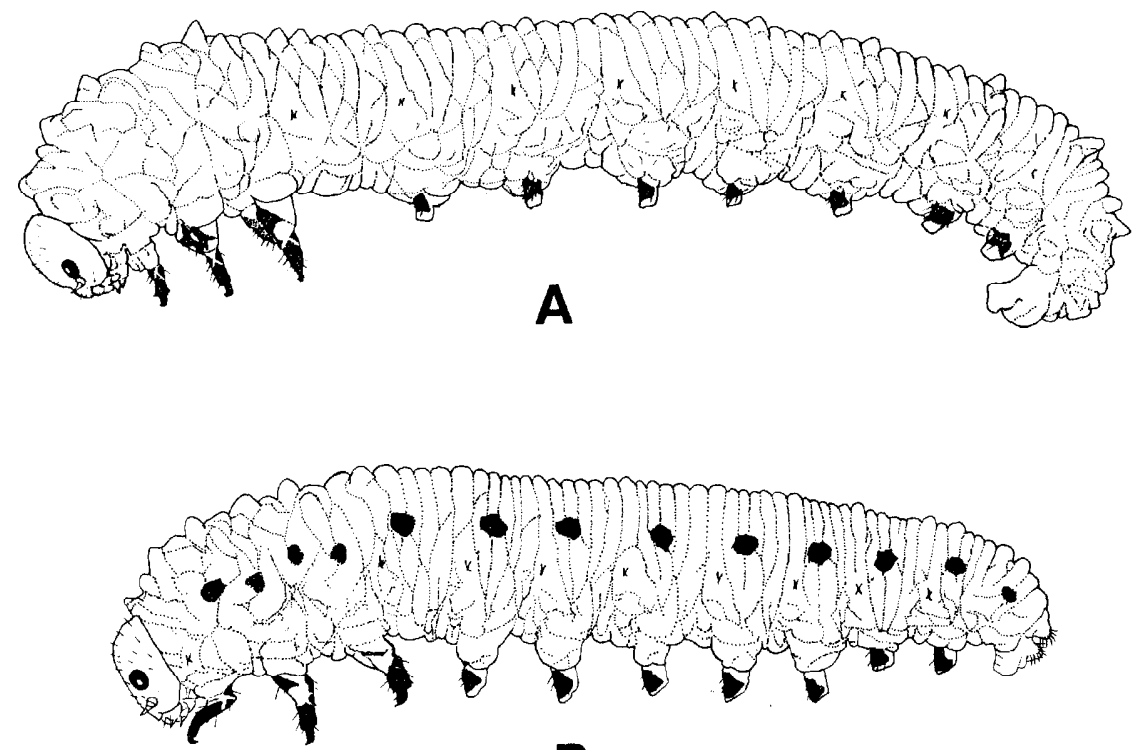

B

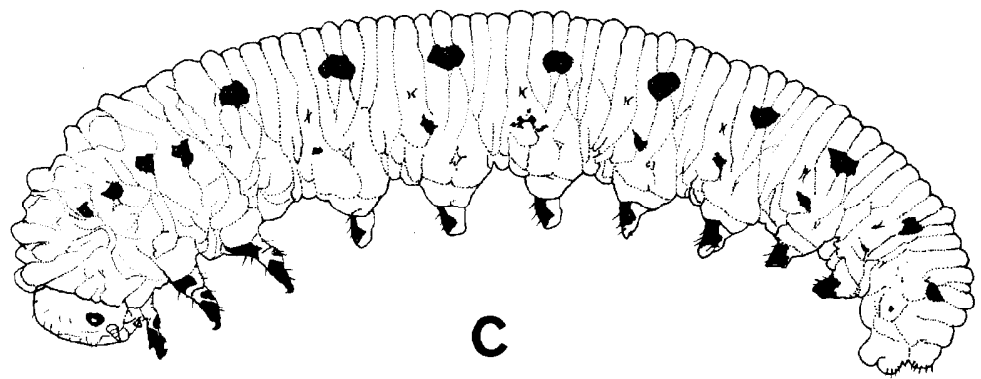

Fig. 7(a). Mature larvae. A : A. japonica, B : A. infumata, C: A. proxima.

from the 3th instar. The color is black with purple tint in A. japonica, A. infumata, A. proxima, and A. rosae ruficornis, but is dark brown with grayish tint in A. kashmirensis and A. yanoi. In the final instar larvae of each species, basically the 5th instar male and the 6th instar female as shown in Table 1 , the color becomes paler than the penultimate one.

Characteristics common to all the Japanese species are the narrow dark line on the dorsum, the faint lateral band across the spiracles, and the concolorous legs and prolegs with the body. But one or two rows of black spots are laterally present in A. infumata and A. proxima. A. proxima is distinguished from A. infumata by having one more subdorsal rows of small black spots (Fig. 7, B-C).

Dorsal fleshy process (Fig. 7)

As stated before, the larvae of Japanese Athalia are provided with conspicuous wart-like processes dorsally. Their distributional pattern is constant as follows : 1 pair on 1st and 2nd annulets of prothorax, 2 pairs on 2nd annulets of meso $^{-}$and metathorax, 3 pairs on 4th annulets of meso- and metathorax, 2 pairs on 2 nd and 3rd annulets of 1 st abdominal segment, and 2 pairs on 2 nd and 4th 

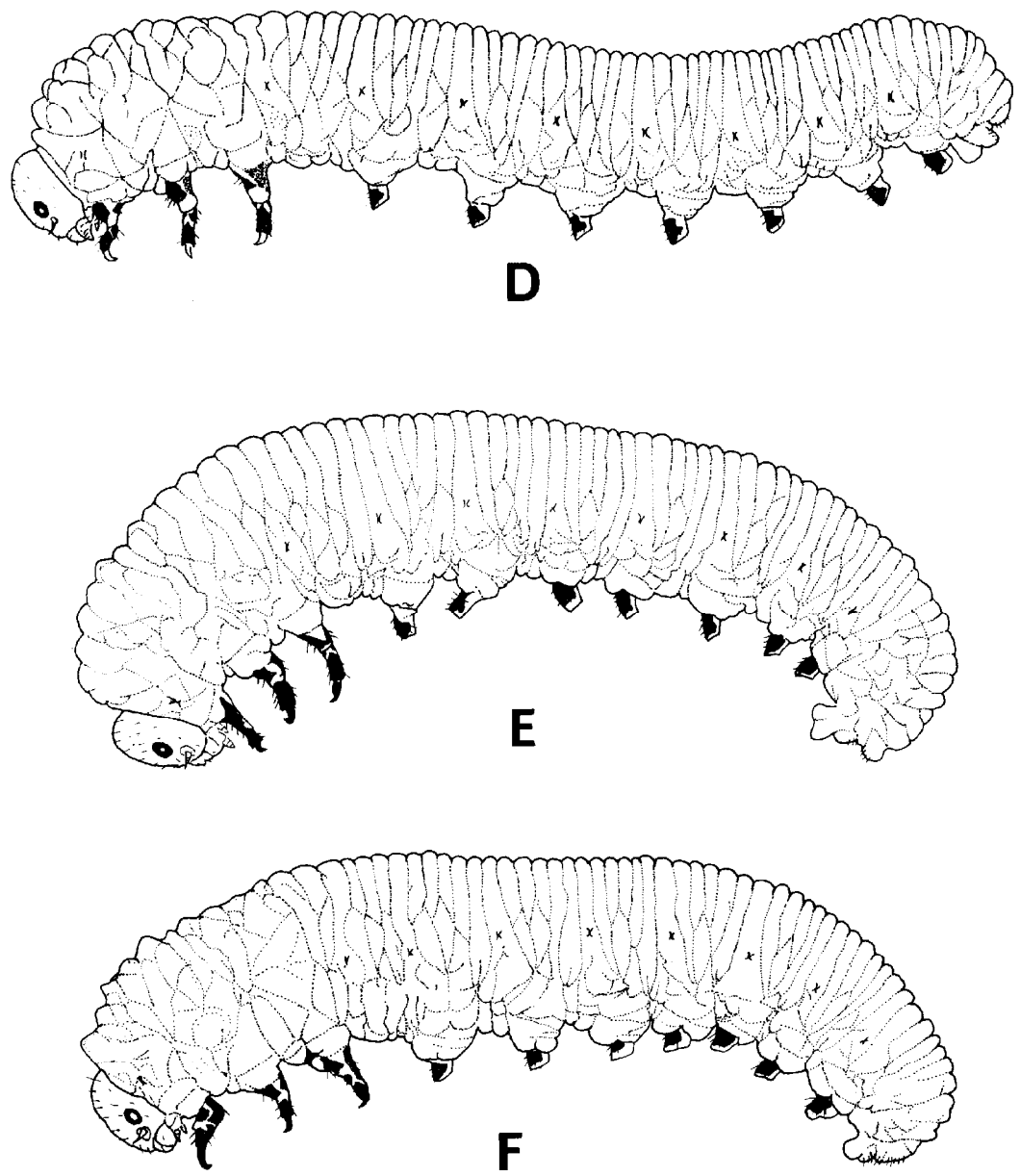

Fig. 7(b). Mature larvae. D:A. rosae ruficornis, E: A. kashmirensis, F: A. yanoi.

annulets of 2nd-9th abdominal segments. Thoracic processes are distinctly bigger than those on the abdomen.

These processes vary in size according to species. The thoracic processes are well-developed in A. japonica, intermediate in A. infumata and A. proxima, and weakly developed in A. rosae ruficornis, A. kashmirensis and $\mathbf{A}$, yanoi.

Mouth-parts (Figs. 8;9)

The larval mouth-parts are basically similar to one another in the Japanese Athalia species as follows: mandibles with two setae, sinistral one with 5 proxadentes, dextral with 4 proxadentes, distadentis subdivided. Maxillary palpi with 4 segments, apical segment longest, 1st segment with 1 seta, 2nd segment with 2 setae; palpifer large with 3 setae; lacinia with 5-6 setae along apical margin. Labium subdivided into pre- and postmentum ; labial palpi with 3 segments, 1st segment with 1 setae, 2nd segment with 2 setae; palpifer with 3 setae. 

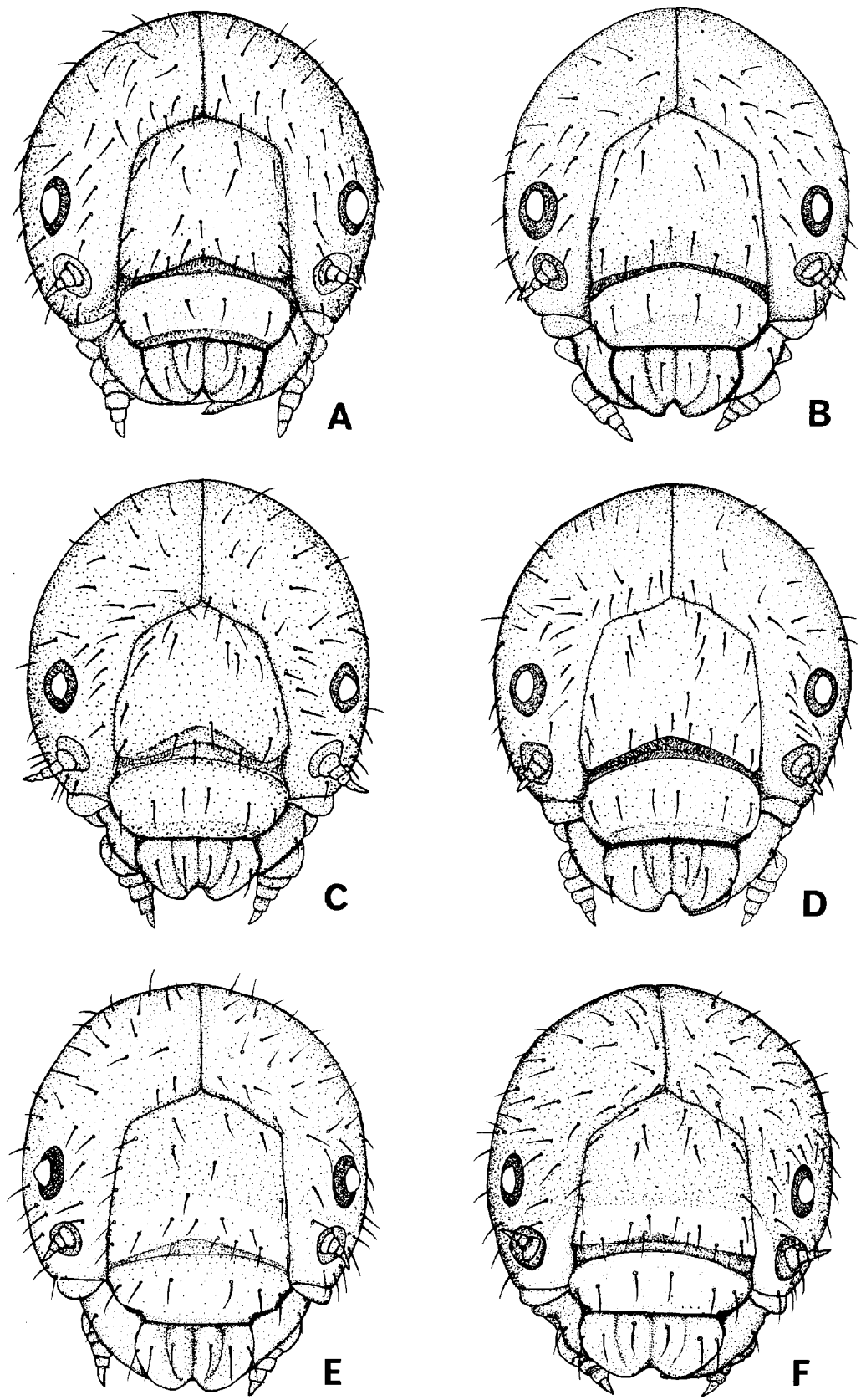

Fig. 8. Larval heads in frontal view. A : A. japonica, B : A. infumata, C : A. proxima, D : A. rosae ruficornis, E : A. kashmirensis, F : A. yanoi. 

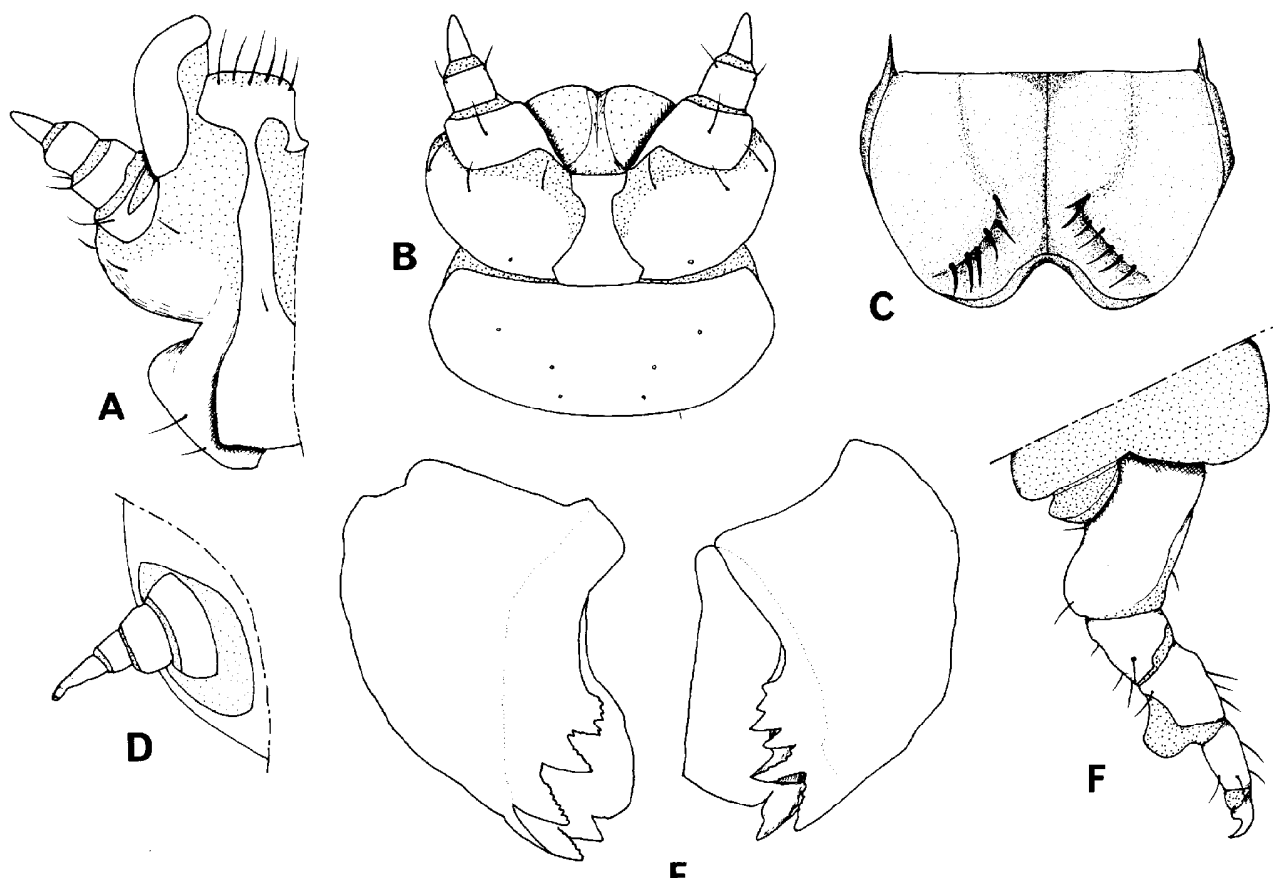

E

Fig. 9. Mouth-parts (A-E) and legs (F) of larva of A. japonica. A : maxilla in frontal view, B : labium in frontal view, $\mathrm{C}$ : epipharynx, D : antenna in lateral view, $\mathrm{E}:$ mandibles in ventral view, $\mathrm{F}$ : hind leg in posterior view.
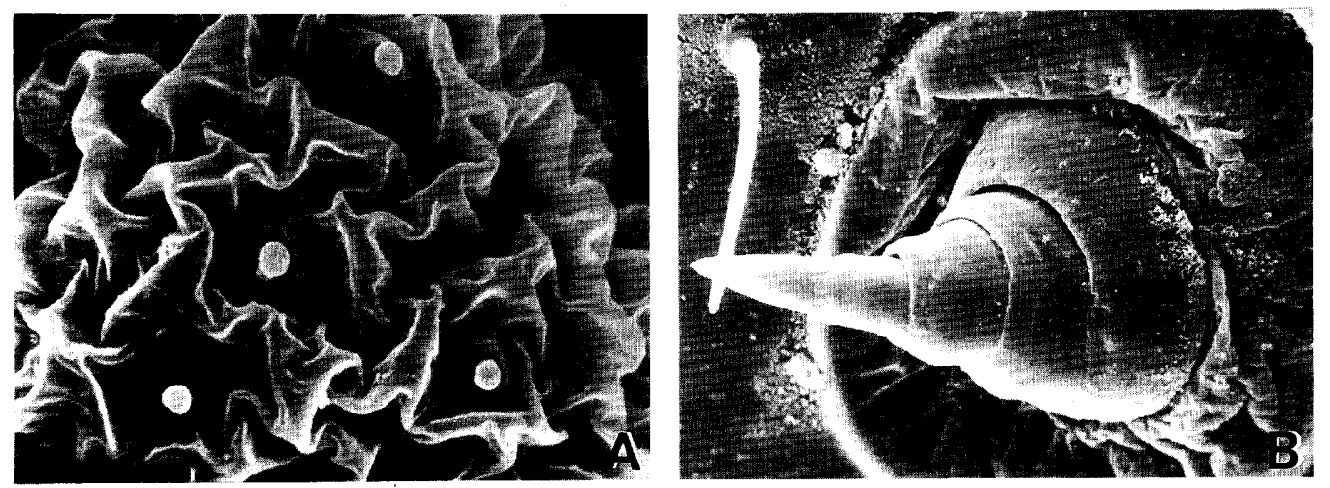

Fig. 10. A. japonica, SEM micrographs of larva. A: fleshy tubercles with microsetae in the 3rd thoracic segment ; B : antenna. 
Table 1. Width of larval head capsule $(\mathrm{mm})$. (): number of individuals.

\begin{tabular}{ccclc}
\hline Instar & japonica & infumata & rosae ruficornis & kushmirensis \\
\hline 1 & $0.46 \pm 0.01(33)$ & $0.44 \pm 0.02(20)$ & $0.42 \pm 0.02(10)$ & $0.40 \pm 0.01(30)$ \\
2 & $0.61 \mathrm{t} 0.02(30)$ & $0.59 \pm 0.01(20)$ & $0.60 \pm 0.0(10)$ & $0.58 \pm 0.02(21)$ \\
3 & $0.85 \mathrm{t} 0.01(32)$ & $0.77 \pm 0.02(20)$ & $0.77 \pm 0.02(10)$ & $0.81 \pm 0.01(20)$ \\
4 & $1.10 \pm 0.03(32)$ & $1.02 \mathrm{f} 0.03(18)$ & $1.08 \pm 0.04(12)$ & $1.01 \pm 0.04(22)$ \\
$5 \odot$ & $1.39 \pm 0.04(36)$ & $1.23 \pm 0.04(15)$ & $1.36 \pm 0.03(8)$ & $1.40 \pm 0.03(16)$ \\
$\sigma^{9}$ & $1.18 \pm 0.04(16)$ & $1.14 \pm 0.03(20)$ & $1.31 \pm 0.03(9)$ & $1.21 \pm 0.03(11)$ \\
$6 \uparrow$ & $1.45 f 0.04(18)$ & $1.29 \pm 0.03(51)$ & $1.50 \pm 0.03(16)$ & $1.50 \pm 0.01(9)$ \\
\hline
\end{tabular}

Legs (Fig. 9, F)

Each femur has either a membraneous or sclerotized projection ventro-distally. The projection is sclerotized only in $A$. kushmirensis.

\section{Sexual difference}

The mature female larva has a pair of small black structures on the ventral side of the 9th abdominal segment ; its function is not known. The male does not have it.

The number of antennal segments (Fig. 10, B)

Lorenz \& Kraus (1957) remarked that the larval antenna is 5-segmented in the Athalia species of Europe. Later, Okutani (1959) also described that it is 5-segmented in Japanese species, A. japonica, A. infumata, and A. rosae mficomis. However, according to my opinion, it is $\$$-segmented in all the Japanese species. Therefore, the validity of the reports of Lorenz \& Kraus and those of Okutani is questioned.

\section{Chromosome number}

The haploid chromosome number (n) of tenthredinid species ranges from 5 to 22 . It is most frequent at $\mathrm{n}=10$ (Naito, 1982).

For $A$. japonica, A. rosae ruficornis and A. infumata, the haploid chromosome number was 8 (Fig. 11, A-C). This observation coincides with the results of Naito (1982). For A. kashmirensis, it was 6 (Fig. 11, D). My observations and those of Naito indicate that the chromosome number is stable in each species.

Thus, the Japanese species of Athalia may be divided into two groups on the basis of the chromosome numbers. These two groups coincide well with the grouping based on clypeus structures and food habits.

\section{Biology}

\section{Host plants}

The host plants of the genus Athalia are restricted to herbaceous species in the families Compositae, Crassulaceae, Cruciferae, Labiatae, Plantaginaceae, Ranunculaceae and Scrophular iaceae (Benson, 1962).

Some species that attack cruciferous crops are known to be agricultural pests in many parts of the world : cabbage sawflies in Europe (Benson, 1962) and China (Chu \& Wang, 1963), and mustard sawflies in India (Maxwell-Lefroy, 1908). In Japan, A. japonica, A. rosae ruficornis, $A$. infumata, and A. proxima cause great damage to several vegetables such as Raphanus sativus [Japanese name : Daikon), Brassica campestris (Kabu],Wasabia japonica [Wasabi) and Nasturtium officinale [Oran- 

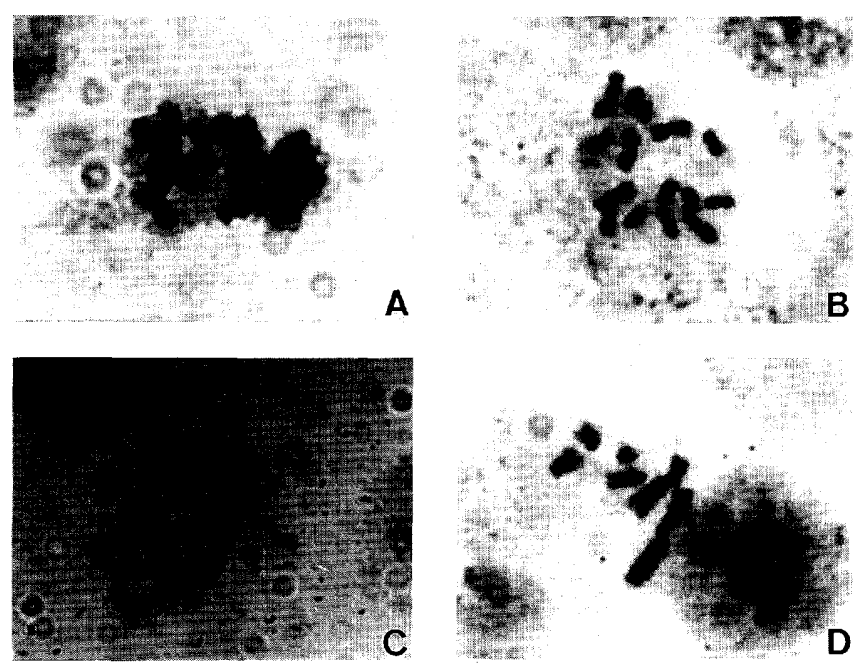

Fig. 11. Chromosome. A-C : diploid metaphases from female embryonic cell, D : haploid metaphase from male embryonic cell.- A : $A$. japonica, B: $A$. infumata, C: A. proxima, D: $A$. kashmirensis.

dagarashi) (Takeuchi, 1949; Okutani, 1967 et al.).

The four species mentioned above also feed on wild plants belonging to several genera in the Cruciferae. Among these species, A. japonica has the widest host range. A. infumata seems to prefer wild plants to cultivated ones. On the contrary, A. rosae meficomis seems to prefer cultivated plants. A. kashmirensis and A. yanoi show the same preference for host plants, Veronica spp. in the Scrophulariaceae. These two species fall in the same species-group based on the shape of clypeus.

As mentioned above, there are no species in Athalia which feed on plants belonging to more than one family as in the case of many other sawflies.

\section{Life history}

\section{Seasonal prevalence}

The seasonal occurrence of adults was investigated in Senami, Murakami-shi, Niigata Pref. and on Mt. Hikosan, Soeda-machi, Fukuoka Pref.

In Senami, Dr. K. Baba systematically collected sawflies by sweeping for two hours everyday (except rainy days) from March to December, 1985 in the coastal dune region and cultivated field.

On Mt. Hikosan, the Malaise trap was set at a narrow pass between a building and cliff on the campus of the Hikosan Biological Laboratory, Kyushu University from March to December, 19691971. The laboratory is located in the broad-leaf forest. The specimens in the trap were brought back into the laboratory every evening and sorted in groups by $\mathrm{Mr}$. K. Takeno.

In Senami (Fig. 12), the following five species were collected : A. japonica, A. rosae ruficornis, A. infumata, A. kashmirensis and A. yanoi. Three species, A. japonica, A. kashmirensis and A. yanoi had two peaks of adult occurrence, one from April to May and the other from September to October. The other two species, A. rosae ruficornis and A. infumata were captured from April to November with about 4 occurrence peaks of the variable size.

On Mt. Hikosan (Fig. 13), the following three species occurred as recorded previously by Togashi 

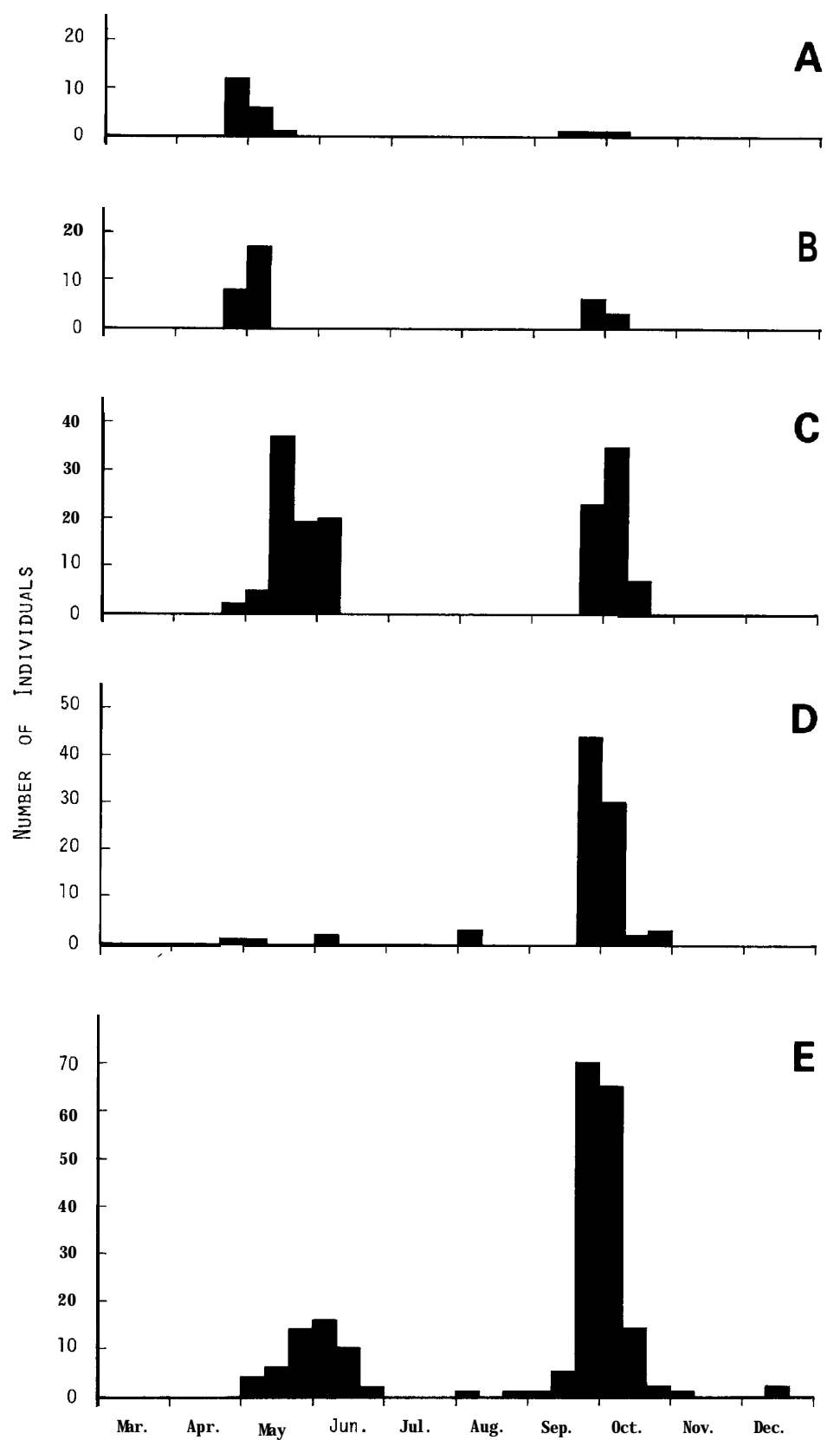

Fig. 12. Seasonal prevalences of Athalia spp. in Senami, Niigata Pref. A : A. yanoi, B :A. kashmirensis, C : A. japonica, D : A. rosae ruficornis, E : A. infumata. 


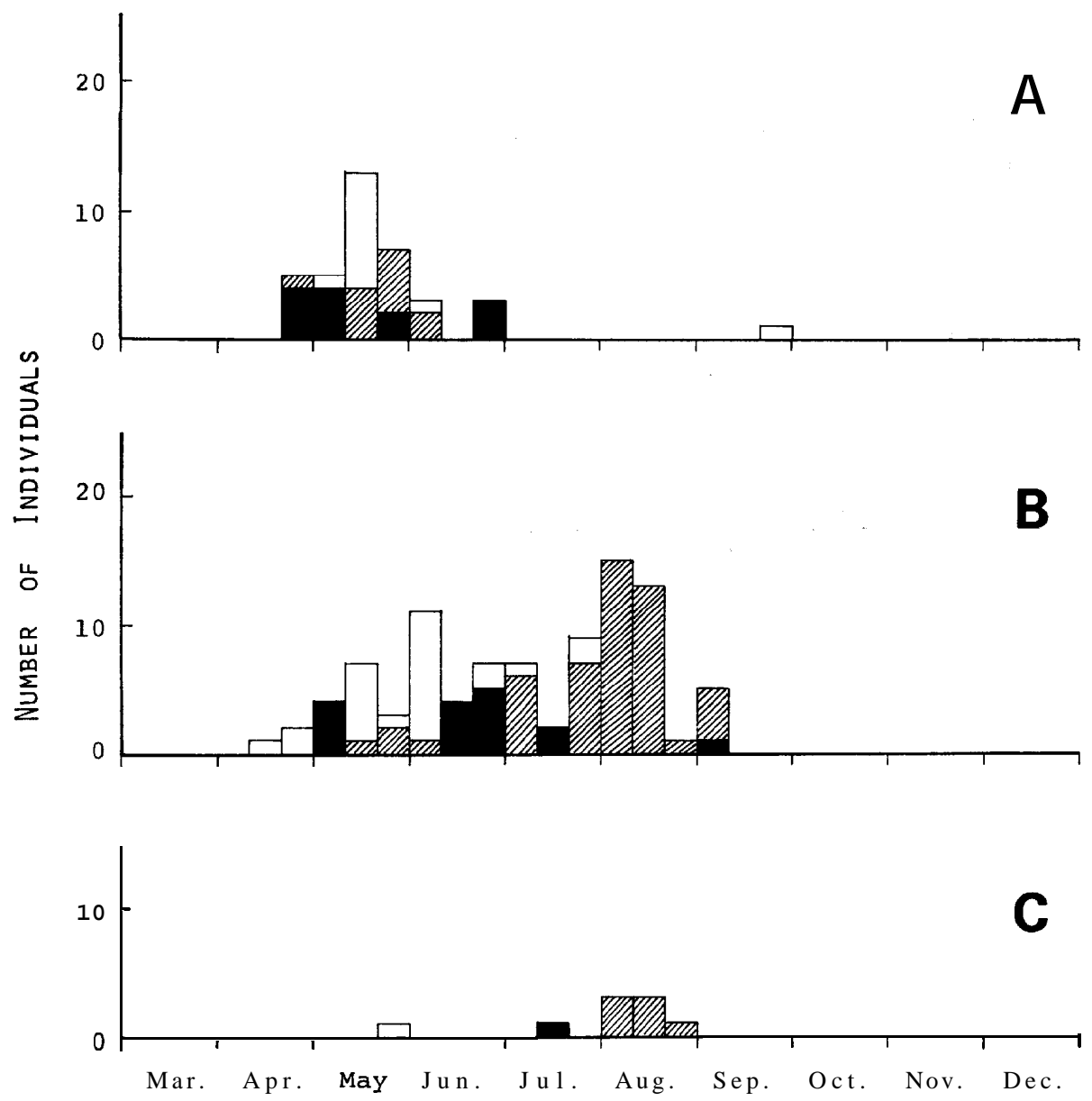

Fig. 13. Seasonal prevalences of Athalia spp. on Mt. Hikosan, Fukuoka Pref. A : A. japonica ; B : A. infumata ; C : A. rosae ruficornis. -Closed section : 1969 ; shaded section : 1970 ; open section : 1971.

(1972) : A. japonica, A. rosae ruficornis, and A. infumata. Among them, A. infumata emerged continuously from April to September, having about 3-4 generations per year. The voltinism of A. rosae ruficornis could not be determined because of insufficient data. Although it has been known that A. japonica has two generations per year, the 2nd generation is inconspicuous as only one specimen was collected during 1969-1971. Moreover, I have never captured this species in autumn there during my five years of sawfly collecting.

Duration of each developmental stage (Fig. 14)

The duration of each developmental stage of four species (A japonica ; A. infumata; A. rosae ruficornis; A. kashmirensis) was determined by rearing 40-50 individuals per species. Eggs were obtained from females captured in FFT in the spring of 1985. They were reared in a transparent glass cylinder of $10 \times 20 \mathrm{~cm}$ on the following food plants : A. japonica, A. infumata, and A. rosae ruficornis on Rorippaindica, and A. kashmirensis on Veronica persica. The adults were fed on diluted honey 
Days after oviposition

0

10

20

30

40

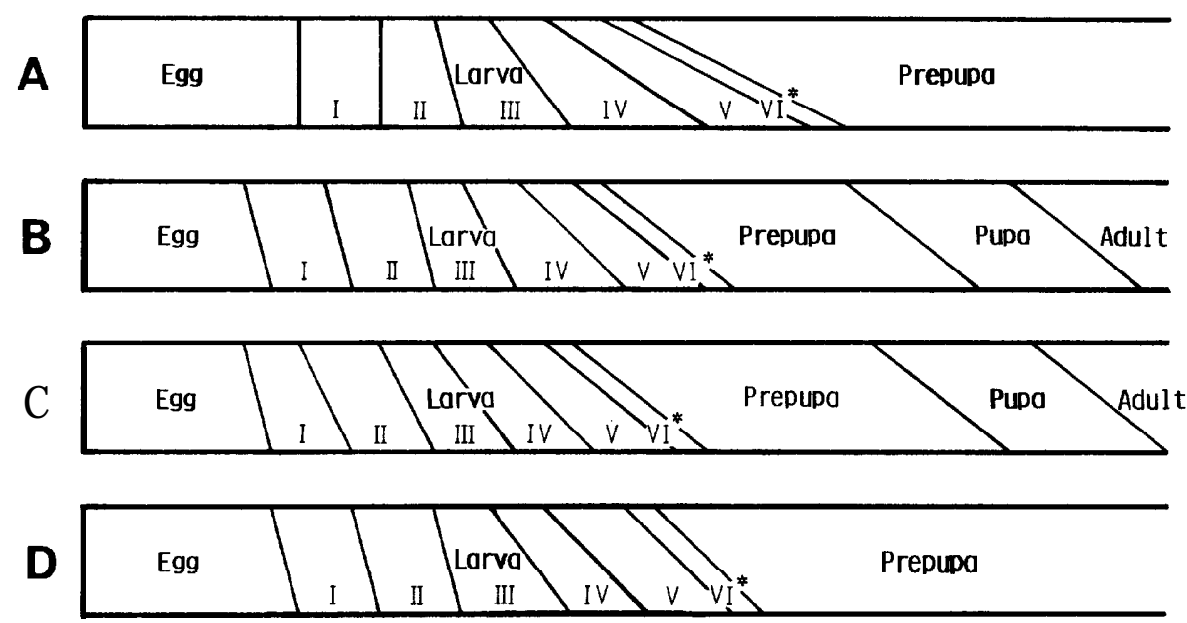

Fig. 14. Development of $A$ thalia spp., schematic $\left(20^{\circ} \mathrm{C}, 16 \mathrm{~L} 8 \mathrm{D}\right) . \mathrm{A}: \mathrm{A}$. japonica, $\mathrm{B}: \mathrm{A}$. infumata, $C$ : A. rosae ruficornis, D: A. kashmirensis. *Female only.

once a day. The eggs deposited in the host plants were kept under a temperature of $20^{\circ} \mathrm{C}$ and $16 \mathrm{~L} 8 \mathrm{D}$ (luminous intensity $: 8 \mathrm{nE} / \mathrm{cm}^{2} \mathrm{sec}$ ). Then, ten eclosed larvae were transferred into a transparent plastic rearing vessel, $10 \times 8 \mathrm{~cm}$. They were reared under the same conditions as those of the eggs. When the larvae matured, 'the vessels were filled with soil to a depth of 2-3 cm for pupation.

The periods required to complete the egg, larval, prepupal and pupal stages were 6-7, 13-17, 9, and 6 days in A. infumata and 6-7, 12-16, 9, and 6 days in A. rosae ruficornis, respectively. The total developmental period was 34-39 days in A. infumata and 35-40 days in A. rosae ruficornis (Fig. 14).

On the other hand, under the same rearing condition, A. japonica and $\mathbf{A}$. kashmirensis entered dormancy in the prepupal stage. A. japonica required 8 and 13-20 days to complete the egg and larval stages, respectively. A. kashmirensis similarly required 7-8 and 14-17 days, respectively. The prepupal period in dormancy lasted 70-90 days in these species. The pupal periods of both species were not ascertained, but it is estimated about 6-7 days as in the case of A. infumata and A. rosae ruficornis.

\section{Life cycle}

Some Athalia species such as A. scutellariae, A. glabricollis, A. lugens and A. liberta have one generation in spring and one in autumn with an interruption by aestivation. Other species such as $A$. rosae rosae are active from spring to autumn and has more than 3 generations per year without aestivation (Benson, 1931a).

Among Japanese species, A. rosae ruficornis and A. infumata are known to have 3 generations per year in Sapporo (Hokkaido) and 6 generations in Fukuoka (Kyushu) from spring to autumn without aestivation. A. proxima has 7-8 generations per year without aestivation in Taiwan (Sonan \& Shibata, 1928). However nothing is known about its life cycle in Japan where it occurs only in limited areas of the Ryukyus. A. japonica and A. kashmirensis each has two generations interrupted by the 
A

\begin{tabular}{|c|c|c|c|c|c|c|c|c|c|c|c|c|}
\hline & Jan. & Feb. & Mar. & Apr. & May & Jun. & Jul. & Aug. & Sep. & Oct. & Nov. & Dec. \\
\hline Egg & & & & & 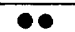 & & & & & 00 & & \\
\hline Larva & & & & & $\bullet$ & & & & & $\bullet$ & 6 & \\
\hline Prepupa & $\bullet \bullet \bullet \bullet$ & 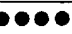 & $\bullet \bullet \bullet$ & 000 & & 000 & 000 & $9 \bullet \bullet$ & $\bullet \bullet \bullet$ & & $\bullet \bullet \bullet \bullet$ & $\bullet \bullet \bullet \bullet$ \\
\hline Pupa & & & & - & - & & & & 0 & 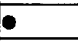 & & \\
\hline Adult & & & & & e日e & & & & & $\bullet \bullet \bullet$ & & \\
\hline
\end{tabular}

$\mathbf{B}$

\begin{tabular}{|c|c|c|c|c|c|c|c|c|c|c|c|c|}
\hline & Jan. & Feb. & Mar. & Apr. & May & Jun. & Ju1. & Aug. & Sep. & 0ct. & Nov. & Dec. \\
\hline Egg & & & & & $\bullet \bullet$ & $\bullet$ & ...... & $\ldots . . . .$. & $\cdots \cdots$ & $\bullet$ & & \\
\hline Larva & & & & & - & $\bullet \bullet \bullet$ & ..... & .......... & $\cdots \cdots$ & & $\bullet$ & \\
\hline Prepupa & $\bullet \bullet \bullet \bullet$ & 000 & $\bullet \bullet \bullet \bullet$ & $\bullet \bullet \bullet \bullet$ & $\bullet$ & $\bullet \bullet$ & ... & $\ldots . . . \ldots$ & $\ldots . . . .$. & & $\bullet \bullet \bullet$ & $\bullet \bullet \bullet \bullet$ \\
\hline Pupa & & & & & $\bullet \bullet$ & $\bullet$ & - & $\ldots \ldots$ & $\cdots \cdots$ & $\cdots$ & & \\
\hline Adult & & & & & $\bullet \bullet \bullet$ & & $\bullet \bullet$ & a....... & A.......... & $\bullet \bullet \bullet \bullet$ & & \\
\hline
\end{tabular}

\begin{tabular}{|c|c|c|c|c|c|c|c|c|c|c|c|c|}
\hline & Jan. & Feb. & Mar. & Apr. & May & Jun. & Jul. & Aug. & Sep. & Oct. & Nov. & Dec \\
\hline Egg & & & & & $\bullet$ & & |....... & $\ldots \ldots$ & $\bullet$ & & $\bullet \bullet$ & \\
\hline Larva & & & & & $\bullet$ & & $\cdots \cdots$ & $\cdots \cdots$ & -1 & 0 & $\bullet \bullet$ & \\
\hline Prepupa & $\bullet \bullet \bullet$ & $\bullet \bullet \bullet \bullet$ & $\bullet \bullet \bullet$ & $\bullet \bullet \bullet$ & & $\bullet$ & ….. & $\cdots \cdots \cdots$ & $\cdots$ & $\bullet$ & $\bullet$ & $\bullet \bullet \bullet \bullet$ \\
\hline Pupá & & & & $\bullet$ & & $\bullet$ & $\cdots$ & $\cdots \cdots \cdots$ & $\cdots$ & $\bullet$ & & \\
\hline Adult & & & & & $\bullet \bullet \bullet$ & $\bullet$ & $\bullet \bullet \cdots$ & ........... & 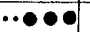 & & 0 & \\
\hline
\end{tabular}

\begin{tabular}{|c|c|c|c|c|c|c|c|c|c|c|c|c|}
\hline & Jan. & Feb. & Mar. & Apr. & May & Jun. & Jul. & Aug. & Sep. & Oct. & Nov. & Dec. \\
\hline Egg & & & & & $\bullet \bullet$ & & & & & $\bullet \bullet \bullet$ & & \\
\hline Darva & & & & & $\bullet \bullet \bullet \bullet$ & & & & $\bullet \bullet \bullet \bullet$ & \\
\hline
\end{tabular}

Fig. 15. Life cycles. A : A. japonica, B : A. infumata, C : A. rosae ruficornis, D : A. kashmirensis.

aestivation. It is also likely that A. yanoi has two generations a year (Fig. 12, A). A. scutellariae also has two active phases in spring and autumn with aestivation. In England it has two reproductively active generations per year (Benson, 1931a), but nothing is known about its biology in Japan.

Masaki (1980) classified the life cycles of insects into 5 major types (A-E) on the basis of seasonal arrangement of active and dormant phases, and subdivided type D and E into three categories (a, b, c) according to the season of reproductive activity. According to Masaki's classifications, $\mathbf{A}$. infumata, A. proxima and A. rosae ruficornis belong to Type A, and A. japonica, A. kashmirensis, A. yanoi, and A. scutellariae to Type Dc.

\section{Habits}

Species of Athalia, like many other sawflies, overwinter in the prepupal stage (Fig. 16, D, center) encased in cocoon (Fig. 16, D, left) in the litter or soil beneath or near the host-plant. Pupation (Fig. 16 , D, right) takes place soon after the onset of warm spring, and emergence of the adults follows in a few weeks. Mating (Fig. 16, A) generally occurs without courtship ; the male approaches the female from behind when she emerges from the soil beneath the host-plant. Copulation of A. proxima was described by Dhillon (1966) and Hussain \& Chatha (1982).

Oviposition began within 20 minutes after mating in the experimental cage. The female selected young and fresh leaves of larval host-plants and deposited milk-white ellipsoidal eggs (avg. size= $0.65 \mathrm{X} 0.96 \mathrm{~mm}$ ) one by one in the tissue of the margin of the leaves tom by her sawing (Fig. 16, B). 
Okutani (1954) observed the swarming of the adults of A. infumata and A. japonica on the leaves of Clerodendrontrichotomum (Japanese name : Kusagi) but the biological significance of this habit is not known.

\title{
Electrophoretic pattern of the larval hemolymph protein
}

Comparative studies on the electrophoretic pattern of the larval hemolymph protein have been carried out in many insects to examine the differences at the intraspecific, interspecific levels and also higher categories. However, no studies have been carried out on sawflies. I studied five Japanese species of Athalia to determine the electrophoretic patterns of the larval hemolymph protein.

1. Total protein of the hemolymph

In order to know whether the geographic variation of the banding pattern exists or not, materials from Kyushu and Hokkaido were compared using A. japonica, A. infumata, and A. rosae ruficornis. No intraspecific variations were found in the main bands stated below.

The effect of the different food-plants was examined using A. japonica that had fed on Rorippa indica and Cardamine leucantha. The results show that food plants had no effect on the main bands.

These results show that the electrophoretic pattern of hemolymph protein is stable in the 5th instar female larvae.

Each species has a specific electrophoretic pattern of the larval hemolymph protein (Fig. 17). Thus, the Rf value of the major components in zone I differs slightly from species to species. A. japonica is characterized by the highest concentration of the median component (Fig. 17, 1). On the contrary, A. kashmirensis and A. yanoi are characterized by their broad components (Fig. 17, 2 \& 3).

2, Amylotic activity of hemolymph

The analyses of amylotic activity of the larval hemolymph protein were also made (Fig. 18). It was also shown that the banding pattern of amylase is stable and species-specific. These amylase bands were classified into two zones (I \& II) according to mobility on gels. In zone II, the Rf value of each band was slightly different from species to species. In zone I, three bands were apparent and the Rf value of each band was more variable : 1 in $\mathbf{A}$. kashmirensis and $\mathbf{A}$. yanoi, $\mathbf{2}$ in $\mathbf{A}$. japonica and A. infumata, and 3 in A. infumata and A. rosae ruficornis.

3, Relationships indicated by electrophoretic analyses

Analyses of the electrophoretic patterns of larval hemolymph protein reveals a close relationship between A. yanoi and A. kashmirensis and a distant relationship between A. japonica and the other species.

\section{Taxonomy}

\section{Genus Athalia Leach}

\author{
Athalia Leach, W., 1817. Zool. Misc., $3: 128$. \\ Type species : (Tenthredo spinarum Fabricius, 1793) = Tenthredo rosae L., 1758. \\ Dentathalia Benson, R. B., 1931. Ent. mon. Mag., 67 : 111. \\ Type species: Athalia scutellariae Cameron, 1880. \\ Adult \\ Length of body 5.0-11.0 mm, forewing 5.0-12.0 mm. \\ Color basically yellow; head and mesonotum mainly black ; legs normally yellow with tibiae \\ and tarsi often black-ringed apically.
}



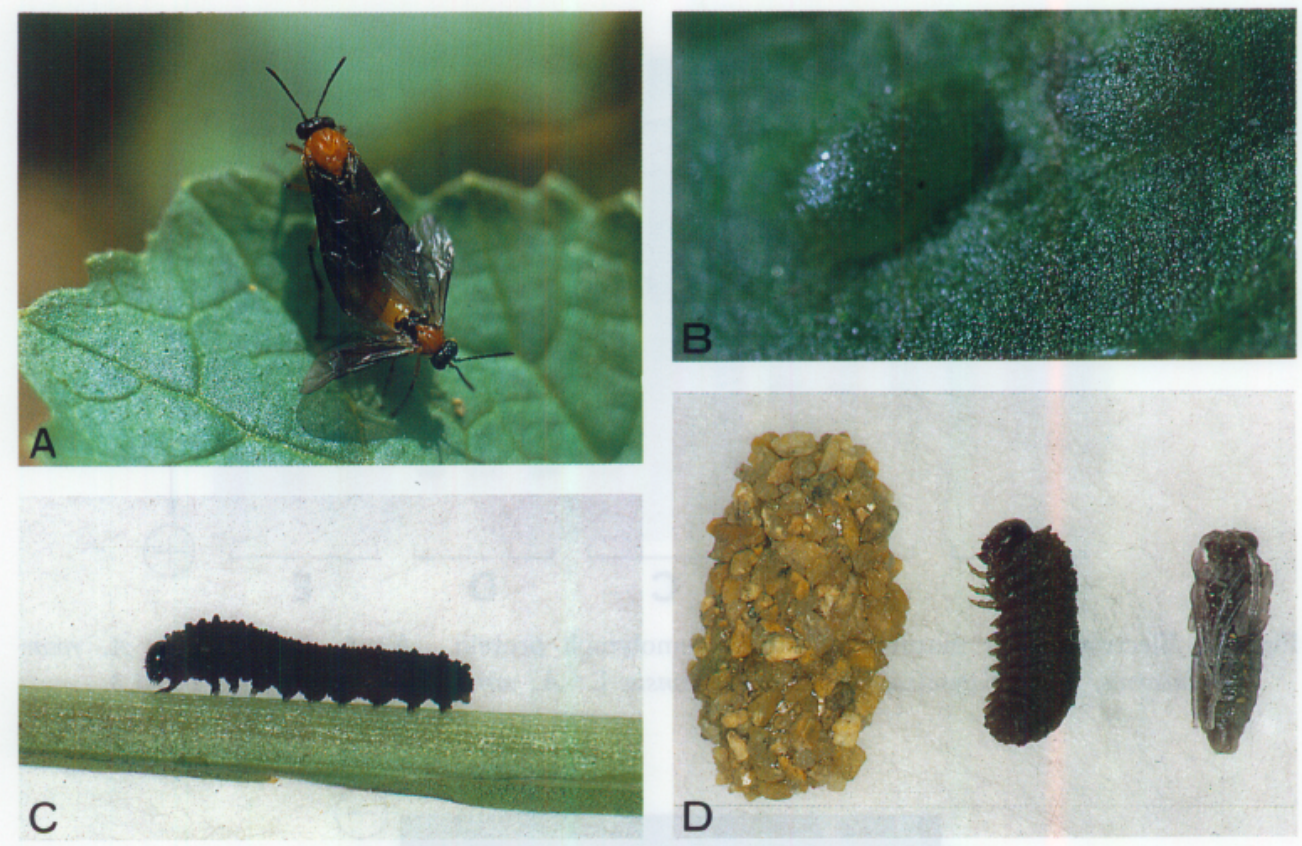

Fig. 16. A. japonica, adult and developmental stages. A : a pair mating on the host-plant, Raphanus sativus ; B : eggs laid in tissue of leaf ; C : 5th instar larva ; D : cocoon (left), prepupa (center), and pupa (right).

Head : Occipital carina absent ; antennae 10-11-segmented (two apical segments almost fused together); flagellum subclavate, with the two basal segments longer than broad; eyes converging below, their lower margins far below antennal sockets ; malar space about equal to distance between antennal sockets or shorter ; clypeus often longer medially than distance between antennal sockets.

Thorax weakly and evenly punctate; cenchri of moderate size ; metapostnotum linear ; mesopleural or 2nd pleural suture strongly sinuate.

Legs : Tarsal claws simple or with inner tooth, not cleft apically ; tibia1 spurs simple.

Wings of generalized tenthredinid type, $\mathrm{C}$ and $\mathrm{Sc}+\mathrm{R}$ in forewing so swollen as almost to obliterate cell $\mathrm{C}, \mathrm{M}$ arises from $\mathrm{Rs}+\mathrm{M}$ which leaves $\mathrm{Sc}+\mathrm{R}$, anal cell complete with oblique cross-vein, and hind wing with 2 enclosed medial cells.

Larva

Length :10-20 $\mathrm{mm}$ in mature larva. Caterpillar-like ; leaf-feeder.

Coloration. Head black; body black-gray.

Head small, sparsely setiferous ; front slightly convex ; a single ocellus on each side of head ; antennae 4- or 5-segmented, slender, elongate-conical; maxillary and labial palpi with 4 and 3 segments, respectively; clypeus subdivided into post- and preclypeus with 3 setae on each side of postclypeus; mandibles with two setae in lateral aspect ; labrum bilaterally symmetrical with a median longitudinal depression and a pair of lateral longitudinal furrows, each lateral lobe with two setae, each median lobe with one seta; epicranial suture and ventral furrows present. 


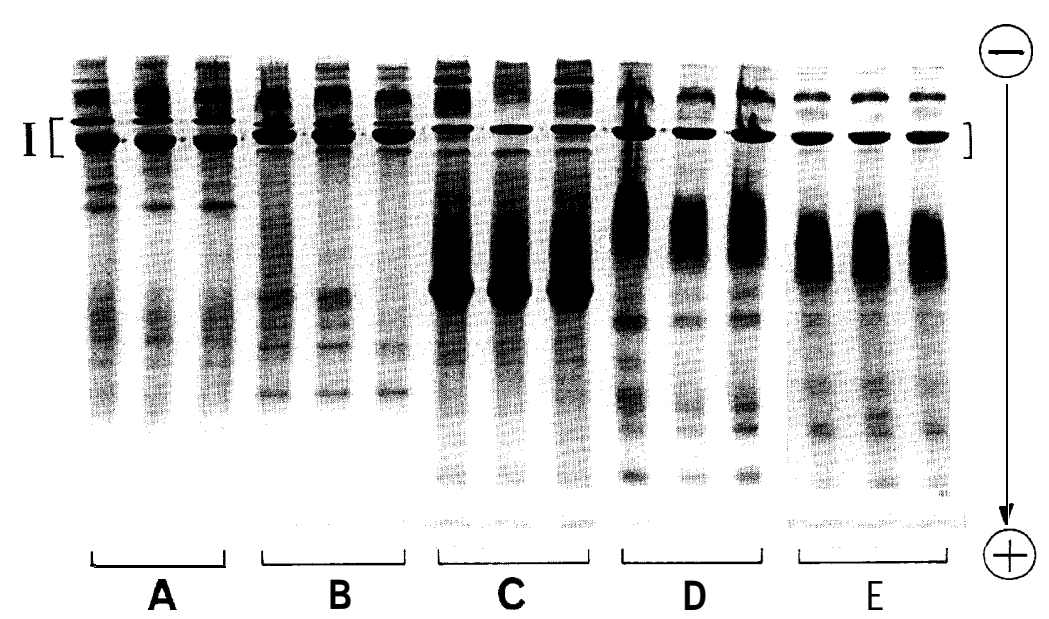

Fig. 17. Electrophoretic patterns of larval hemolymph protein. A : A. infumata, B : A. rosae ruficornis, C : A. japonica, D : A. kashmirensis, E : A. yanoi. See text for I, 1, 2 and 3.

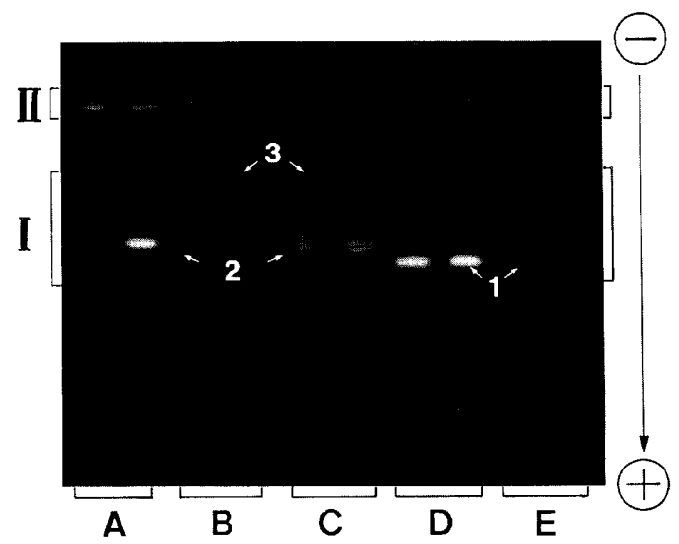

Fig. 18. Electrophoretic patterns of larval haemolymph amylase. A : A.infumata, B : A. rosae ruficornis, C: A. japonica, D : A. kashmirensis, E: A. yanoi. See text for I, II, 1, 2 and 3.

Body cylindrical, with small distinct tubercles; 10th abdominal tergum with several small protuberances ; 3rd abdominal segment with 6 annulets on dorsum ; each annulet with very short and minute conical or spatulate, unbranched spines ; thoracic legs well developed, normal in form, 5segmented; tibiae shorter than or subequal to femora, tarsal claws curved inside ; femora with a membraneous or sclerotized projection ventro-distally; prolegs with about 10 setae on 2nd-8th and 10th abdominal segments, normal in form, subsegmented, distal lobe truncate on distal margin.

Distribution : The Old World.

Host-Plant : Compositae, Crassulaceae, Cruciferae, Labiatae, Plantaginaceae, Ranunculaceae and Scrophulariaceae. 


\section{Keys to Japanese Species of Athalia}

Adults (female and male)

1. Tarsal claws simple

- Tarsal claws with inner tooth in addition to end tooth

scutellariae Cameron

2. Clypeal front margin rounded

Clypeal front margin truncated, the lateral margin (between the anterolateral angle and mandibular articulation) more than half as long as diameter of an antennal socket

3. Tibiae broadly infuscate

Tibiae infuscate only at apices

rosae ruficornis Jakovlev

4. Femora all yellow; all tibiae and tarsi mainly black above; apical margin of female hypopygium slightly convex in the middle

Hind and middle femora black apically; apical margin of female hypopygium excavated with a large triangular projection in the middle (Fig. 5, A)

japonica (Klug)

5. Mesonotum almost entirely black generally, sometimes anterior half yellow, at least mesoscutellum, mesopostnotum and mesoposttergite always black infumata (Marlatt) Mesonotum including scutellum mainly yellow

6. Mesonotum mainly black; tibiae black at apices. yanoi Takeuchi Mesonotum mainly yellow ; tibiae entirely black kashmirensis Benson

Mature larvae

1. Head entirely black ; body black, mat, with slight purple tint (some species with deep black spots laterally); on cruciferous plants

Head black with mouth-parts brownish white ; body dark brown with grayish tint, and with white stripe below spiracular line; on Veronica spp.

2. Body with conspicuous wart-like processes dorsally Body simple, without such processes dorsally rosae ruficornis Jakovlev

3. Body spotted with black above spiracular line Body not spotted, entirely black with purple tint japonica (Klug)

4. Body spotted above every subspiracular lobes proxima (Klug) Body not spotted above subspiracular lobes infumata (Marlatt)

5. Femur with a membraneous projection ventro-distally ; 2nd annulet of prothorax moderately developed dorsally yanoi Takeuchi Femur with a sclerotized projection ventro-distally ; 2nd annulet of prothorax weakly developed dorsally

kashmirensis Benson

\section{A thalia japonica (Klug)}

[Japanese name: Nihon-kabura-habachi]

Tenthredo japonica Klug, 1815, Mag. Ges. naturf.Fr. Berlin, 7: 131 ; Kriechbaumer, 1884, In Klug (ed.), Aufs. Blattwesp., p. 87.

Athalia japonica: Klug, 1834, Jahrb.d. Insektenk., $1: 253$; Kriechbaumer, 1884, In Klug (ed.), Aufs. Blattwesp., p. 298 ; Rohwer, 1910, Proc.U.S. nat. Mus., 39 : 110 ; Takeuchi, 1919, Ins. World, 23(261) : 185 (In Japanese.) ; Yano, 1920, J. Plant Prot., 7(10): 552 (In Japanese.) ; Forsius, 1927, Arkiv zool.,19A(10):6; Yano, 1932, In Uchida et al. (eds.), Icon. Ins. Japon., p. 441, Hokuryukan, 
Tokyo (In Japanese.) ; Takeuchi, 1951, In Esaki et al. (eds.), Icon. Ins. Japon., p. 1342, Hokuryukan, Tokyo (In Japanese.) ; Takeuchi, 1952, A Genetic Classification of the Japanese Tenthredinidae (Hymenoptera: Symphyta), p. 29, Kyoto ; Takeuchi, 1955, In Esaki \& Takeuchi (eds.), Coloured Illustrations of the Insects of Japan, $2: 124$, Hoikusha, Osaka (In Japanese.) ; Okutani, 1959, In Kawada et al. (eds.), Illustrated Insect Larvae of Japan, p. 565, Hokuryukan, Tokyo. (In Japanese.) ; Benson, 1962, Bull. Brit. Mus. (Nat. Hist.) Ent., 11(7) : 370 ; Chu \& Wang, 1962, Acta zool. Sinica, 14(4) : 505-514 (In Chinese.) ; Chu \& Wang, 1963. Acta ent. Sinica, 12(1) : 93-97 (In Chinese.) ; Togashi, 1965, In Yasumatsu et al. (eds.), Icon. Ins. Japon., $3: 250$, Hokuryukan, Tokyo (In Japanese.) ; Okutani, 1977, In Ito et al. (eds.), Coloured Illustrations of the Insects of Japan, $2: 291$, Hoikusha, Osaka (In Japanese.).

Athalia spinarum: Onuki \& Nakagawa (nec Fabricius), 1902, Noji-shiken-jo-hokoku, $23: 48$ (in part : form 1) (In Japanese.).

Athalia novittata Kokujev, 1927, Trav. Comm. Lac Bajkal, $2: 64$.

Biology : Yago, 1929, J. Plant Prot.,16(12): 737-738 ; Narutomi, 1931, Jap. J. appl.Zool., 3: 190193 (In Japanese.) ; Kitano, 1950, Shin Konchü,3(4) : 39-40 (In Japanese.) ; Atarashi, 1953, Ōȳ̄Kontyü,9(1) : 23-29 (In Japanese.) ; Okutani, 1967, Jap. J.appl. Ent. Zool., 11 : 93 (In Japanese.) ; Togashi, 1972, Mushi, Fukuoka, 46: 129-135 ; Uesumi, 1976, In Kishi (ed.), Yasai-nobyo-gai-chu, pp. 479-481, Zenkoku-noson-kyoiku-kyokai, Tokyo (In Japanese.) ; Naito, 1982, Kontyâ, Tokyo, 50(4) : 569-587 ; Baba \& Togashi, 1985, Trans. Essa ent. Soc., 60: 3-8 (In Japanese.)

\section{Female}

Spring form

Coloration. Head black ; clypeus, labrum and basal 1/3 of mandibles dark brown ; apical $1 / 3$ of mandibles reddish brown ; palpi brown. Thorax orange ; mesaxillae, mesopostnotum except for median portion, metanotum except for median portion and metapostnotum black ; median portion of mesopostnotum and metanotum yellowish brown. Wings hyaline ; tinged with dark brown; veins brownish black. Legs orange ; dorso-apical portion of middle and hind femora, tibiae except for ventral portion, and tarsi except for basal portion of 1 st and 2nd tarsomeres black ; tibial spurs brown. Abdomen yellowish orange; 1st abdominal tergite except for the posterior margin of proximal area black; the area yellowish brown; ovipositor sheath black.

Structure. Antennae 11-segmented (the two apical segments almost fused together) with all segments longer than broad ; clypeus almost symmetrical, only slightly rounded in front and not angled laterally ; prelabium shorter than diameter of eye ; malar space $1 / 3$ as long as distance between antennal sockets. Tibial spurs long (hind inner spurs about as long as tibial width) ; tarsal claws simple. Hypopygium excavated with a large triangular projection in the middle. Saw with shallow blunt teeth, each tooth with 20-25 denticulations.

Pubescence pale throughout ; dense and infuscate on head above, bare on dorsal surfaces of 2-8 abdominal tergites.

Measurements (in mm) : Body length 6.2-11.3 (avg.= 7.6) ; forewing length 6.5-12.1 (7.8) ; head width 1.5-2.3 (1.8) ; thorax width 2.1-3.0 (2.5) ; 3rd antennal segment length (0.96) ; 8th antenna1 segment (length $\mathbf{x}$ width) $(0.26 \mathbf{x} 0.18)$; 9 th antennal segment (length $\mathbf{x}$ width) $(0.22 \times 0.18)$; malar space $(0.05)$; distance between antennal sockets $(0.16)$; eye (shortest diameter $\mathbf{x}$ longest diameter) $(0.64 \times$ 1.09); hind tibia1 inner spur length (0.29).

Autumn form

Differs from the spring form as follows: Head more rounded in front view ; bases of antenna1 

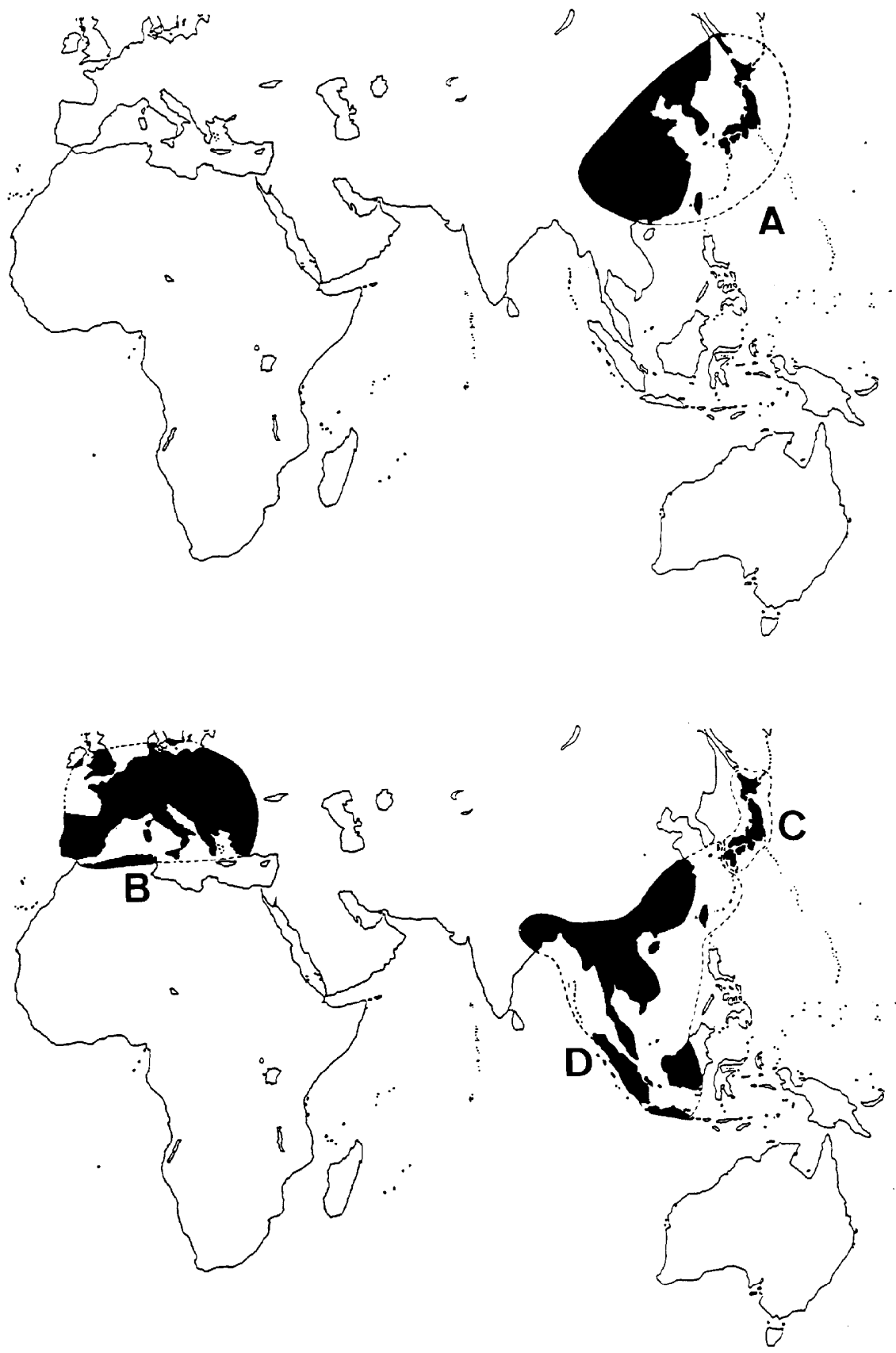

Fig. 19(a). Distribution of Athalia spp. A : A. japonica, B : A. lugens, C : A. infumata, D : A. proxima. 

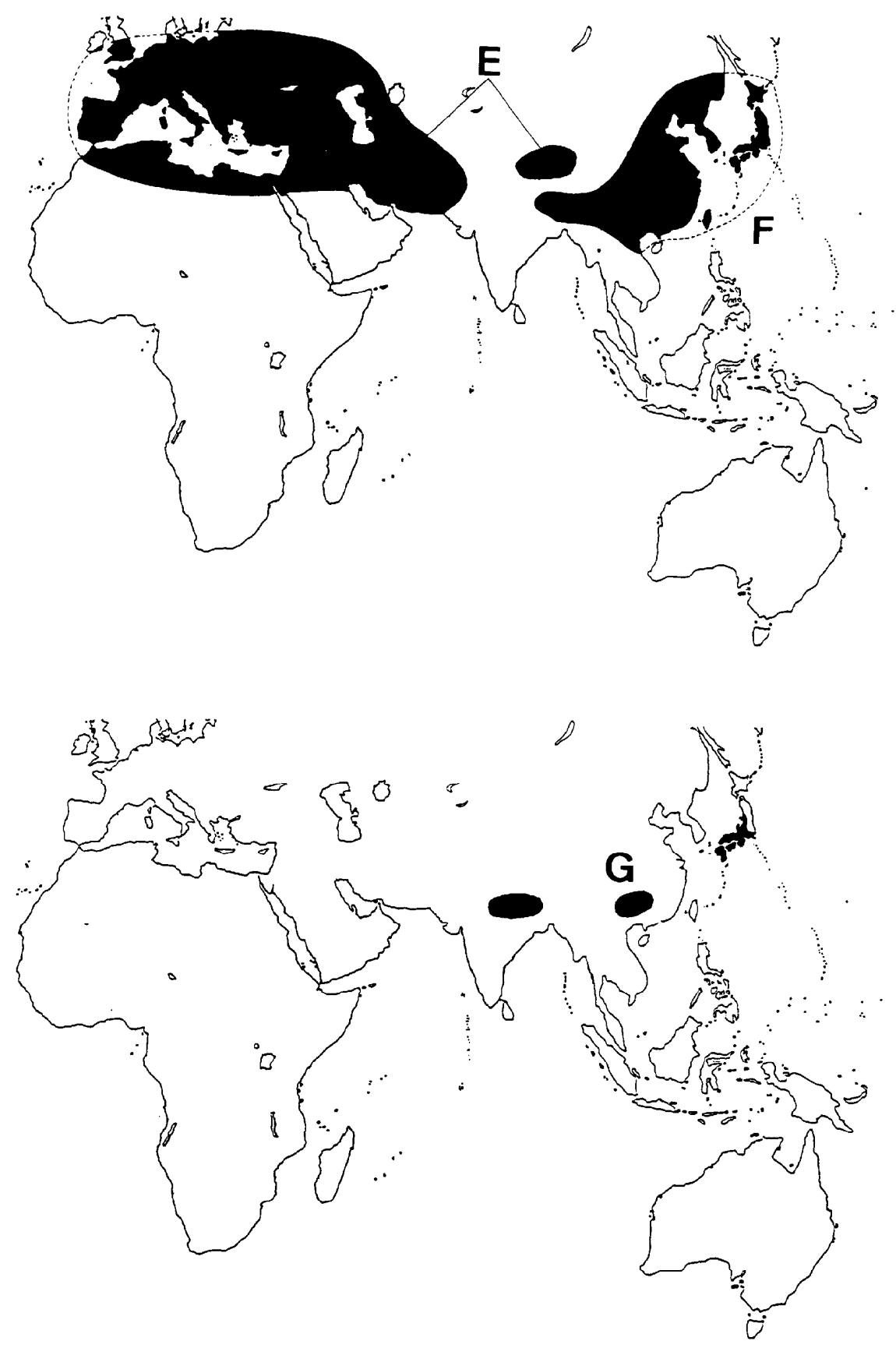

Fig. 19(b). E : A. rosae rosae, $\mathrm{F}$ : A. rosae ruficornis, G :A. kashmirensis. 

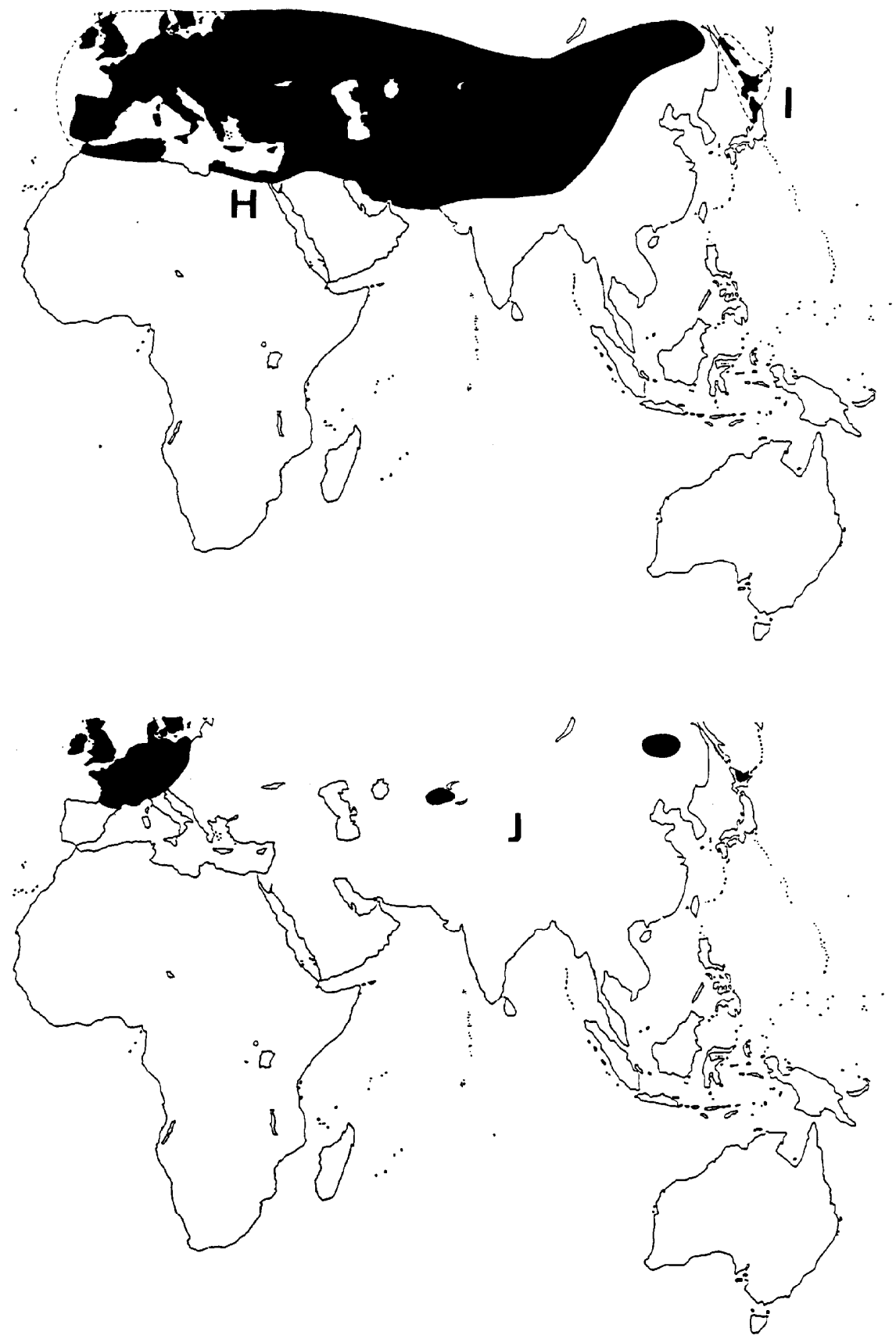

Fig. 19(c). H : A. liberta, I : A. yanoi, J : A. scutellariae. 
sockets, lower portion of space between antennal sockets, clypeus, and basal $2 / 3$ of mandibles yellowish brown ; labrum, apical $1 / 3$ of mandibles and palpi brown. Legs orange ; dorso-apical portion of middle and hind femora, hind tibia except for ventral and median $1 / 3$, apical $2 / 3$ of fore and middle tibiae, and tarsi except for basal portion of 1 st and 2 nd tarsomeres black ; tibia1 spur brown.

Measurements (in mm) : Body length 5.4-5.9 (5.6) ;forewing length 5.5-6.1 (5.8) ; head width 1.21.5 (1.3) ; thorax width 1.6-2.2 (1.9) ; 3rd antennal segment length (0.71); 8th antennal segment (length $\mathbf{x}$ width) $(0.19 \times 0.13)$; 9 th antennal segment (length $\mathbf{x}$ width) (0.16 $\mathbf{x} 0.13)$; malar space $(0.04)$; distance between antennal sockets (0.12) ; eye (shortest diameter $\mathbf{x}$ longest diameter) (0.47 $\mathbf{x} 0.81)$; hind tibia1 inner spur length $(0.21)$.

\section{M ale}

Coloration. Similar to female, but differs as follows. Head : bases of antennal sockets, lower portion of space between antennal sockets, and ventral portion of scape yellowish brown ; clypeus, labrum, and basal $2 / 3$ of mandibles brownish white ; apical $1 / 3$ of mandibles brown ; palpi orange. Leg : dorso-apical portion of hind and middle femora, hind tibia except for ventral and median $1 / 3$ ringed portions, apical $1 / 3$ of fore and middle tibiae, basal portion of 1st and 2nd tarsomeres black ; tibia1 spur brown. Abdomen yellowish orange ; 1st abdominal tergite except for the posterior margin of proximal area black; the area yellowish brown.

Structure. Similar to female, but eyes strongly converging below, and malar space very short. Genitalia (Fig. 6, A) : gonostylus long and somewhat curved inwardly, with a triangular ventral process ; cuspis large and broad ; digitus short and pointed; interior swelling well developed.

Measurements (in $\mathrm{mm}$ ) : Body length 4.6-8.3 (6.1) ; forewing length 4.3-8.1 (5.7) ; head width 1.5 - 2.1 (1.8) ; thorax width 1.5 - 2.1 (1.8) ; malar space (0.01) ; distance between antenna1 sockets (0.09) ; eye (shortest diameter $\mathrm{x}$ longest diameter) ( $0.66 \mathrm{X} 1.16)$.

Mature Larva (5th instar larva) (Figs. 7, A ; 8, A ; 9, A-F ; 10, A-B)

Length $14-20 \mathrm{~mm}(\mathbf{n}=28$, avg. $=16.8 \mathrm{~mm})$; size of head capsule as shown in Table 1 . Head black ; front with 22-23 setae ; mouth-parts dark-brown. Body black, mat, with slight purple tint ; thoracic wart-like processes well-developed ; abdominal ones moderately developed ; femoral projection membraneous.

Material examined. Adults : 32599 and $5510^{\top} \sigma^{7}$ from all parts of Japan (except for Okinawa Pref.). Larvae : 55 exs. from the following localities : FFT, FMJ, FSH, HKT, HTA, and OKK.

Distribution : Japan, Formosa, Korea, China, and East Siberia (Fig. 19, A).

Host-Plants : Arabis hirsuta (Linn.) Scop. [Japanese name : Yamahatazao) on Mt. Shioji, Fukuoka Pref. ;Cardamine yezoensis Maxim. (Ezowasabi) in Tennin-kyo, Kamikawa Prov. Hokkaido ; Cardamine leucantha (Tausch) 0. E. Schulz (Konronso)on Mt. Hikosan, Fukuoka Pref. ; Curdamine appendiculata (Franch. et Savat.) Matsum. [Hirohakonronso] in Hirogawara, Nagano Pref. ; Nasturtium officinale R. Br. (Orandagarashij in Zomeki, Yamaguchi Pref. (new records). Arabis glabra (Linn.) Bernh. [Hatazao) ; Cardamine impatiens Linn.〔Janinjin]; Cardamine flexuosa With. (Tanetsukebana] ; Raphanus sativus Linn. var. hortensis Backer [Daikon];Wasabia japonica (Miquel) Matsum. [Wasabi) ; Rorippaindica (Linn.) Hochr. (Inugarashi) ; Brassica campestris Linn. var. glabra Kitam. (Kabu〕; Brassica campestris Linn. var. amplexicaulis subvar. Petsai Kitam. (Hakusai) ; Brassica chinensis L. var. Komatsuna Matsum. et Nakai (Komatsuna); Brassica Japonica var. japonica Schulz [Shakushina) (Okutani, 1967). All belong to the Cruciferae.

LIFE-CYCLE : Bivoltine ; a reproductively active phase in spring and autumn, respectively, with aestivation in Japan (Fig. 15, A).

Chromosome number : Female, $2 \mathrm{n}=16$; male, $\mathrm{n}=8$. Locality : Mt. Iwawakisan, Osaka Pref. ; 
Mt. Rokkosan, Hyogo Pref. (Naito, 198‘2) ; FFT ; FMJ ; FSH (new records) (Fig. 11, A).

Eiectrophoretic pattern of tarval hemolymph protein: As shown in Fig. 17, C. Locality: FAH, FFT, FMJ, FSH, and HTA. Food-plant: Rorippa indica and Cardamine leucantha.

Natural enemy: Perilampus ?aeneus Rossi (Hymenoptera, Perilampidae) ex prepupa (new record). It is well known that the female of Perilampus deposits her eggs at random on the plant leaves.

\section{A thalia infumata (Marlatt)}

[Japanese name : Seguro-kabura-habachi]

Phyllotoma infumata Marlatt, 1898, Proc.U.S. nat. Mus., $21: 494$.

Athalia spinarum: Onuki \& Nakagawa (nec Fabricius), 1902, Noji-shiken-jo-hokoku, 23 : 49 (in part: form 3) (In Japanese.).

Athalia Zugens infumata: Rohwer, 1910, Proc.U. S. nat. Mus., 39 : 110; Takeuchi, 1919, Ins. World, 23(261) : 185 (In Japanese.) ; Yano, 1920, J. Plant Prot.,7(10): 553-554 (In Japanese.) ; Yano, 1932, In Uchida et al. (eds.), Icon. Ins. Japon., p. 442, Hokuryukan, Tokyo (In Japanese.) ; Benson, 1932, Ann. Mag.nat. Hist., 10(9): 183-188 ; Takeuchi, 1951, In Esaki et al. (eds.). Icon. Ins. Japon., p. 1343, Hokuryukan, Tokyo (In Japanese.) ; Takeuchi, 1952, Gen. Class.Jap. Tenthredinidae, p. 29; Takeuchi, 1955, In Esaki \& Takeuchi (eds.), Coloured Illustration of the Insects of Japan, 2 : 124, Hoikusha, Osaka (In Japanese.) ; Okutani, 1959, In Kawada et al. (eds.), Illustrated Insect Larvae of Japan, p. 565, Hokuryukan, Tokyo (In Japanese.) ; Benson, 1962, Bull. Brit.Mus. (Nat. Hist.) Ent., 11(7) : 370 ; Togashi, 1965, In Yasumatsu et al. (eds.), Icon. Ins. Japon., 3: 250, Hokuryukan, Tokyo (In Japanese.) ; Okutani, 1977, In Ito et al. (eds.), Coloured Illustrations of the Insects of Japan, $2: 291$, Hoikusha, Osaka (In Japanese.).

Atkalia nigronotum Matsumura, 1912, Thous. Ins. Japan, Suppl., 4 : 68; Yano, 1920, J. Plant Prot., 7(10) : 554 (In Japanese.).

Athalia lugens var. camtschatica : Forsius, 1928, Notul. ent. Helsingf., 8: 46; Benson, 1932, A nn. Mag. nat. Hist., 10(9) : 183-188 ; Takeuchi, 1952, Gen. Class. Jap. Tenthredinidae, p. 29.

Athalia lugens tibialis: Takeuchi (nec Cameron), 1952, Gen. Class. Jap. Tenthredinidae, p. 29.

Biology : Narutomi, 1931, Jap. J. appl.Zool., 3: 190 - 193 (In Japanese.) ; Atarashi, 1953, Oyy Kontyū., 9(1) : 23-29 (In Japanese.) ; Okutani, 1967, Jap. J.appl. Ent. Zool., 11: 93 (In Japanese.) ; Togashi, 1972, Mushi, Fukuoka, 46 : 129-135; Uesumi, 1976, In Kishi (ed.),Yasai-no- byo-gai-cku, pp. 479-481 ; Naito, 1982, Kontyû, Tokyo, 50(4) : 569-587 ; Baba \& Togashi, 1985, Trans. Essa ent. Soc., 60 : 3-8 (In Japanese.).

Benson (1962) divided A. lugens into 3 subspecies : A. 1. lugens from Europe, A. 1. infumata from Japan and A. 1. proxima from South-East Asia. According to my opinion, however, infumata and proxima represent a distinctive species, respectively. The cuspis of male genitalia is rounded in lugens (Chevin, 1968), while it is hooked at the apex in infumata. European lugens feeds on the ranunculaceous plants (Clematis spp.) (Anderê, 1879 and Vassilev, 1978), but the Japanese infumata feeds on the cruciferous plants. According to Benson (1931a), lugens has an aestivation, but infumuta does not have it. The status of proxima is discussed below.

\section{Female}

Adult (Figs. 2, D ; 3, B-C ; 4, B ; 5, B ; 6, B)

Coloration. Head black ; clypeus, labrum and basal $1 / 3$ of mandibles dark brown ; apical $1 / 3$ of mandibles reddish brown ; palpi and ventral portion of antennae brown. Thorax orange ; dorsum 
entirely black except for pronotum, anterior margin in lateral lobe of mesonotum and tegulae ; sometimes anterior half of mesoscutum orange. Wings hyaline ; tinged with gray; veins blackish brown. Legs orange ; tibiae except for ventral portions, and tarsi except for basal portion of 1st and 2nd tarsomeres black; tibial spur brown. Abdomen yellowish orange ; 1 st and 2nd abdominal tergites black; ovipositor sheath black.

Structure. Antennae U-segmented (the two apical segment almost fused together) with all segments longer than broad; clypeus only slightly rounded in front and not angulated laterally ; prelabium shorter than diameter of eye ; malar space $1 / 4$ as long as distance between antenna1 sockets. Tibial spurs long (hind inner spur about as long as tibial width); tarsal claws simple. Hypopygium with posterior margin slightly convex in the middle. Saw with shallow blunt teeth, each tooth with 20-25 denticulations.

Pubescence pale throughout ; dense and infuscate on head above ; bare on dorsal surfaces of 2-8 abdominal tergite.

Measurements (in mm). Body length 5.4-7.8 (6.3) ; forewing length 5.7-8.4 (7.0) ; head width 1.52.3 (1.9) ; thorax width 1.7-2.5 (2.1) ; 3rd antenna1 segment length (0.46); 8th antenna1 segment (length $\times$ width) $(0.24 \times 0.18)$; 9 th antennal segment (lengthx width) $(0.14 \times 0.18)$; malar space $(0.06)$; distance between antennal sockets $(0.26)$; eye (shortest diameter $\times$ longest diameter) $(0.58 \mathbf{x} 1.06)$; hind tibial inner spur length $(0.26)$.

\section{$\mathrm{M}$ ale}

Coloration. Similar to female, but differs as follows. Head : clypeus, labrum, basal $2 / 3$ of mandibles and ventral portion of scape brownish white; apical $1 / 3$ of mandibles reddish brown ; palpi orange; ventral portion of antennae except for scape brown. Abdomen yellowish orange ; proximal portion of 1 st abdominal tergite black.

Structure. Similar to female, but eye strongly converging below, and malar space very short. Genitalia (Fig. 6, B) : gonostylus strongly curved inwardly, with a triangular ventral process ; cuspis moderately large and broad, hooked apically; digitus broadly flattened, weakly constructed subapically; interior swelling well developed.

Measurements (in mm) : Body length 4.8-6.2 (5.4) ; forewing length 4.8-6.2 (5.4) ; head width 1.5-1.9 (1.7) ; thorax width 1.5-1.9 (1.7) ; malar space (0.05) ; distance between antennal sockets (0.11) ; eye (shortest diameter $\times$ longest diameter) $(0.68 \times 1.03)$.

M ature Larva (5th instar larva) (Figs. 7, B ; 8, B)

Length : 12-17 mm $(\mathrm{n}=31$, avg. $=15.6 \mathrm{~mm})$; size of head capsule as in Table 1. Head black ; front with 17 setae; mouth-parts dark brown. Body black, mat, with purple tint ; meso- and metathorax with two black spots laterally; 1st-9th abdominal segments with a larger black spot above each spiracle; thoracic wart-like processes moderately developed-femoral projection membraneous.

Material examined. Adults :192 $\$$ a and 34366 from all parts of Japan. Larvae : 142 exs. from the following localities : HRT, HTA, FFT, FMJ, and FSH.

Distribution : Japan (except Ryukyu Isls.), Sakhalin, and Chishima Isls. (Fig. 19, C).

Host-Plant : Cardamine flexuosa With. (Tanetsukebana) on Mt. Hikosan, Fukuoka Pref. ; Nasturtium officinale R. Br. [Orandagarashi) in Sawara-myoken, Fukuoka (new records). Rorippa indica (Linn.) Hochr. (Inugarashi) ; Brassica campestris Linn. var. glabra Kitam. [Kabul ; Raphanus sativus var. hortensis Backer [Daikon] (Okutani, 1967). All belong to the Cruciferae.

Life-CYCLE : Multivoltine ; 3 (Hokkaido)-6 (Kyushu) generations per year from spring to autumn without aestivation (Fig. 15, B).

C нRомоsome number : Female, $2 \mathrm{n}=16$; male, $\mathrm{n}=8$. Locality: Mt. Rokkosan, Hyogo Pref. 
(Naito, 1982), FFT and FSH (new records) (Fig. 11, B).

Electrophoretic pattern of LARVAl hemolymph protein: As shown in Fig.17, A. Locality: FFT and HRT. Food-plant : Rorippaindica.

Natural enemy : Perilampus?aeneus Rossi (Hymenoptera : Perilampidae) ex prepupa (new record).

\section{Athalia proxima (Klug)}

[Japanese name : Ryukyu- kabura-habachi (new name)]

Ten thredo proxima Klug, 1815, Mag. Ges. naturf. Fr. Berlin, $7: 130$; Kriechbaumer, 1884, In Klug (ed.), Aufs. Blattwesp., p. 86.

Athalia proxima : Klug, 1834, Jahrb.d. Insectenk., $1: 253$; Norton, 1867, Trans. Amer. ent. Soc., 1 : 460 ; Kirby, 1882, List Hym. Brit. Mus., 1(12): 235 ; Kriechbaumer, 1884, In Klug (ed.), Aufs.

Blattwesp., p. 298 ; Dhillon, 1966, Alig. Musl. Univ. Publ.(Zool.Ser.) Indian Ins. Typ., 7 : 1-144.

Athalia tibialis Cameron, 1876, Trans. ent. Soc. Lond., 3(10):460; Cameron, 1877, Proc. nat. Hist. Soc. Glasgow, $3: 130$.

A thalia spinarum var. orientalis Cameron, 1877, Trans. ent. Soc. Lond., 2(6) : 90 ; Cameron, 1882, Monogr. Brit. Phytoph. Hym., I: 307.

A thalia proxima var. funebris Forsius, 1925, Notul. ent. Helsingf., $5: 91$.

Athalia colibri var. kuroiwae Matsumura \& Uchida, 1926, Ins. Mats., $1: 70$.

Athalia orientalis: Forsius, 1927, Arkiv Zool., 19A(10): 7.

Athulia lugens tibialis: Benson, 1932, Ann. Mag. nat. Hist., 10(9) : 183-188.

Athalia lugens proxima:Benson, 1932, Ann. Mag. nat. Hist., 10(9) : 183-188; Takeuchi, 1952, Gen. Class. Jap.Tenthredinidae, p. 29 ; Benson, 1962, Bull. Brit. Mus. (Nat. Hist.) Ent., 11(7): 370 ; Chu \& Wang, 1962, Acta zool. Sinica, 14(4): 505-514 (In Chinese.) ; Chu \& Wang, 1963, Acta Ent. Sinica, 12(1) : 93-97 (In Chinese.).

Athalialugens var. tristis Forsius, 1934, Rev. suisse Zool.,41(4): 106.

Biology : Maxwell-Leafroy, 1908, Mem. Dep. Agric. India Ent., l(6) : 357-370 ; Sonan\& Shibata, 1928, Trans. nat. Hist. Soc. Formosa, 18(94) : 49-64 (In Japanese.) ; Hussain \& Chatha, 1982, Pakistan J.Zool., 14(1): 117-118.

A. proxima is similar to A. infumata so far as the shape of the cuspis and digitus of male genitalia, food habits and life cycle are concerned (these separated from European lugens), but is separated from infumata by the absence of the interior swelling on the male gonocoxite and the presence of an additional row of small black spots on the body below the spiracle in the larva.

\section{F emale}

A dult (Figs. 2, E; 3, D ; 4, C; 5, C ; 6, C)

Coloration, Head black ; clypeus, labrum and basal $1 / 3$ of mandibles dark brown ; apical 1/3 of mandibles reddish brown ; palpi brownish yellow. Thorax orange ; mesaxillae, mesoposttergite, mesopostnotum, metanotum and metapostnotum black. Wings hyaline; tinged with dark brown; veins brownish black. Legs orange ; tibiae except for ventral portion and tarsi except for basal portions of 1st and 2nd tarsomeres black ; tibial spur brown. Abdomen yellowish orange ; ovipositor sheath black.

Structure. Antennae lo-segmented with all segments longer than broad ; clypeus only slightly rounded in front and not angled laterally, prelabium shorter than diameter of eye ; malar space $1 / 2$ as long as distance between antennal sockets. Tibial spurs long (hind inner spur about as long as 
tibia1 width); tarsal claws simple. Hypopygium with apical margin slightly convex in the middle. Saw with shallow blunt teeth; each tooth with 20-25 denticulations.

Pubescence pale throughout ; dense and infuscate on head above, bare on dorsal surfaces of 2-8 abdominal tergites.

Measurements (in mm) : Body length 6.0-7.8 (6.8) ; forewing length 5.9-7.7 (6.7) ; head width 1.6-2.2 (1.9) ; thorax width 1.7-2.5 (2.2) ; 3rd antenna1 segment length $(0.53)$; 8th antenna1 segment (length $\mathrm{x}$ width) $(0.18 \mathrm{x} 0.19)$; 9 th antennal segment (length $\mathrm{x}$ width) $(0.16 \mathrm{x} 0.22)$; malar space $(0.1)$; distance between antennal sockets $(0.2)$; eye (shortest diameter X longest diameter) $(0.73 \mathrm{X} 1.04)$; hind tibia1 inner spur length (0.25).

M ale

Coloration. Similar to female, but differs as follows. Head : clypeus, labrum, and basal $2 / 3$ of mandibles whitish brown ; apical $1 / 3$ of mandibles dark brown ; palpi brown ; ventral portion of antennae whitish brown.

Structure. Similar to female, but eye strongly converging below, and malar space very short. Genitalia (Fig. 6, C): gonostylus strongly curved inwardly, with a triangular ventral process ; cuspis moderately large and broad, hooked apically; digitus broadly flattened, weakly constructed subapically ; interior swelling absent.

Measurements (in mm) : Body length 5.8-6.9 (6.3) ; forewing length 4.9-6.0 (5.4) ; head width 1.5-2.1 (1.8); thorax width 1.4-2.0 (1.7); malar space (0.01); distance between antenna1 sockets $(0.18)$; eye (shortest diameter $\mathrm{x}$ longest diameter) $(0.75 \mathrm{x} 1.05)$.

\section{M ature Larva (Figs. 7, C ; 8, C)}

Length : $12 \mathrm{~mm}(\mathrm{n}=3)$. Head black ; front with 17 setae ; mouthparts dark brown. Body black, mat, with purple tint and with black lateral spots as in A. infumata, but differs from the latter in having additional small black spots on 2nd-9th abdominal segments below the spiracles.

Material examined. Adults :48우 and $780 \sigma^{7}$ from the following localities. JAPAN :KyushuFukuoka Pref. : Okinoshima Is. Nagasaki Pref. : Nishidomari, Tsushima Is. (Tsutsu, Shushi, Sasuna, Naiin, Shiine, Komada). Kagoshima Pref. : Amami-ohshima Is. (Yuwan). Okinawa Pref. : Ishigaki Is. (Kabira, Kainan, Shiraho, Ohama) ; Okinawa Is. (Kyan-misaki, Misato, Naha, Ginama, Nago, Hentoma, Katsuyama, Mt. Yonaha, Izumi, Gushiehan, Shuri, Nakagusuku, Chinen, Tamagusuku) ; Miyako Is. (Karimata, Shimoji, Gusukube). FORMOSA : Taipei. Larvae : 3 exs. from the following localities : OIK and KTN.

Distribution : Japan (Tsushima \& Ryukyu Isls.), South China, Formosa, Borneo, Java, Malaya, South India and Burma (Fig. 19, D).

Host-Plant : Brassica napus L. ; Brassica nigra (L.) Koch ; Brassica Juncea L. ; Brassica rapa L. ; Raphanus raphanistrium L. (Benson, 1962). All belong to the Cruciferae.

LIFE-CYCLE : Multivoltine ; 7-8 generations per year from spring to autumn without aestivation in Formosa (Sonan \& Shibata, 1928). In Japan, nothing is known about its life cycle.

Karyotype, electrophoretic pattern of larval hemolymph protein, and natural enemy are unknown.

\section{Athalia rosae ruficornis Jakovlev}

[Japanese name : Kabura-habachi]

A thalia spinarum var. ruficomis Jakovlev, 1888, Horae Soc. ent. ross., 22 : 373.

Athalia spinanum: Onuki \& Nakagawa (nec Fabricius), 1902, Noji-shiken-jo-hokoku, 23 : 48 (in 
part : form '2) (In Japanese.).

Athalia leucostoma Cameron, 1904, Z. syst. Hym.Dipt., 1(6) : 108.

Athalia spinarum japanensis Rohwer, 1910, Proc.U. S. nat. Mus., $39: 109$.

Athalia colibri: Matsumura (nec Christ), 1912, Thous. Ins. Japan, $4: 67$ (In Japanese.).

Athalia colibri japanensis: Takeuchi, 1919, Ins.World,23(261) : 185 (In Japanese.) ; Yano, 1920, J. Plant Prot., 7(10) : 550-551 (In Japanese.) ; Yano, 1932, In Uchida et al. (eds.), Icon. Ins. Japon., P. 441, Hokuryukan, Tokyo (In Japanese.).

Athatia rosae japonensis: Takeuchi, 1951, In Esaki et al. (eds.), Icon. Ins. Japon., p. 1342, Hokuryukan, Tokyo (In Japanese.) ; Okutani, 1977, In Ito et al. (eds.), Coloured Illustrations of the Insect of Japan, 2 : 291, Hoikusha, Osaka (In Japanese.).

Athalia rosae japonica : Okutani, 1959, In Kawada et al. (eds.), Illustrated Insect Larvae of J\& an, p. 564, Hokuryukan, Tokyo (In Japanese.).

Athalia rosae ruficomis: Benson, 1962, Bull. Brit.Mus. (Nat. Hist.) Ent., 11(7): 370 ; Chu \& Wang, 1962, Acta zool. Sinica, 14(4) : 505-514 (In Chinese.) ; Zombori, 1972, Acta zool. Acad.sci. hung., $18(3 \&$ 4) : 441.

Athalia rosae japanensis: Takeuchi, 1952, Gen. Class. Jap. Tenthredinidae, p. 29 ; Chu \& Wang, 1963, Acta ent. Sinica, 12(1) : 93-97 (In Chinese.).

Biology : Yanata, 1906, Saishin-sakumotsu-gaichu-hen, pp. 224-228, Bunbudo, Tokyo (In Japanese.) ; Narutomi, 1931, Jap.J.appl.Zool., 3 : 190-193 (In Japanese.) ; Oda, 1936, Engeigaichu-zuhen, pp. 251-252, Meibundo, Tokyo, (In Japanese.) ; Takahashi, 1948, Nogyo-gaichuhen, pp. 171-172, Youkendo, Tokyo (In Japanese.) ; Yuasa \& Kawada, 1952, Nosakumotsu-gaichushin-setsu, pp. 369-371, Asakura, Tokyo (In Japanese.) ; Atarashi, 1953, Ōyō-Kontyū, 9(1) : 23-29 (In Japanese.) ; Tsutsui, 1960, Genshoku-seitai-sakumotsu-gaichu-zufu, p. 162, Youkendo, Tokyo (In Japanese.) ; Okutani, 1967, Jap.J. appl. Ent. Zool., 11 : 93 (In Japanese.) ; Chikaoka, 1968, In Nomura (ed.), Genshoku-byogaichu-shindan-boujo-hen, 3 : 42-44, No-san-gyo-son-bunka-kyokai, Tokyo (In Japanese.) ; Togashi, 1972, Mushi, Fukuoka, 46: 129-135 ; Uesumi, 1976, In Kishi (ed.), Yasai-no- byogaichu, pp. 479-481, Zenkoku-noson-kyoiku-kyokai, Tokyo (In Japanese.) ; Okuno et al., 1978, Diseases and Pests of Flowers and Vegetables in Colour, p. 49, Hoikusha, Tokyo (In Japanese.) ; Naito, 1982, Kontyû, Tokyo, 50(4) : 569-587 ; Baba \& Togashi, 1985, Trans. Essa ent. Soc., 60 : 3-8 (In Japanese.).

\section{Female}

Adult (Figs. 2, F ; 3, E-F ; 4, D; 5, D ; 6, D)

Coloration. Head black ; clypeus, labrum and basal $1 / 2$ of mandibles whitish ; apical $1 / 2$ of mandibles whitish brown; ventral portion of antennae reddish brown ; palpi orange. Thorax orange ; postero-distal portion of lateral lobe of mesoscutum, mesaxillae, mesoposttergite, mesopostnotum, metanotum except for the median portion, and metapostnotum black. Wings hyaline ; tinged with dark brown; veins brownish black. Legs orange ; apical ringed portion of tibiae, and apical $1 / 2$ ringed portions of 1st-4th tarsomeres, and 5th tarsomere black. Abdomen yellowish orange ; proximal portion of 1 st abdominal tergite and ovipositor sheath black.

Structure. Antennae lo-segmented with only 8th and 9th segments broader than long; clypeus only slightly rounded in front and not angled laterally ; prelabium shorter than diameter of eye ; malar space as long as distance between antennal sockets. Tibial spurs long (hind inner spur about as long as tibial width) ; tarsal claws simple. Hypopygium slightly excavated with a small triangular projection in the middle. Saw with shallow blunt teeth ; each tooth with 20-25 denticulations.

Pubescence pale throughout ; dense and infuscate on head above, bare on dorsal surfaces of 2-8 abdominal tergites. 
Measurements (in mm) : Body length 6.2-7.8 (6.7) ; forewing length 6.3-7.9 (6.8) ; head width 1.8-2.6 (2.2); thorax width 1.8-2.5 (2.1) ; 3rd antennal segment length (0.56); 8th antenna1 segment (length $\times$ width) $(0.23 \times 0.18)$; 9 th antennal segment (length $\mathrm{X}$ width) $(0.21 \times 0.23)$; malar space $(0.15)$; distance between antennal sockets $(0.16)$; eye (shortest diameter $\mathrm{x}$ longest diameter $(0.61 \mathrm{x} 0.94)$; hind tibia1 inner spur length (0.23).

Male

Coloration. Similar to female, but differs as follows : Head : clypeus, labrum, and basal $2 / 3$ of mandibles whitish; apical $1 / 3$ of mandibles reddish brown; ventral portion of antennae reddish brown. Abdomen : distal spotted portion of 1 st abdominal tergite black.

Structure. Similar to female, but eye strongly converging below, and very short malar space. Genitalia (Fig. 6, D) : gonostylus long and somewhat curved inwardly, with a weakly developed triangular ventral process ; cuspis and digitus short and broad, spatulate ; interior swelling well developed.

Measurements (in mm) : Body length 5.1-5.9 (5.5) ; forewing length 5.2-6.0 (5.6) ; head width 1.2-1.6 (1.4) ; thorax width 1.2-1.4 (1.3) ; malar space (0.06); distance between antenna1 sockets (0.16) ; eye (shortest diameter $\mathrm{x}$ longest diameter) $(0.7 \times 1.0)$.

Mature Larva (5th instar larva) (Figs. 7, D ; 8, D)

Length : 12-17 mm ( $\mathbf{m = 2 1}$, avg. $=15.2)$; size of head capsule as in Table 1. Head black ; front with 20-21 setae; mouth-parts dark brown. Body black, mat, with slight purple tint ; thoracic wartlike processes weakly developed ; femoral projection membraneous.

Material examined. Adults :60ㅇ and $360^{7} \sigma^{\circ}$ from all parts of Japan (except for Okinawa Pref.). Larvae : 42 exs. from the following localities : HKS, FFT, and FMJ.

Distribution : Japan, Formosa, Korea, China, Himalayas and East Siberia (Fig. 19, F).

Host-plant : Cardamine flexuosa With. (Tanetsukebana] in Kikuchi-keikoku, Kumamoto Pref. ; Nasturtium officinale R. Br. (Orandagarashi] in Zomeki, Yamaguchi Pref. (new rocords). Rorippa indica (Linn.) Hochr. [Inugarashi] ; Raphanus sativus var. hortensis Backer (Daikon]; Brassica campestris Linn. var. glabra Kitam. 〔Kabu〕; Brassica campestris Linn. var. amplexicaulis subvar. Petsai Kitam. (Hakusaij (Okutani, 1967). All belong to the Cruciferae.

LIFE-CYCLE : Multivoltine ; 3 (Hokkaido)-7 (Okinawa Pref.) generations per year during springautumn without aestivation in Japan (Fig. 15, C).

Chromosome number : Female, $2 n=16$; male, $n=8$. Locality ; Mt. Iwawakisan, Osaka Pref. ; Mt. Rokkosan, Hyogo Pref. (Naito, 1982) ; FFT (new record) (Fig. 11, C).

Electrophoretic pattern of larval hemolymph protein : As shown in Fig. 17, B. Locality : FAH, FFT, and HKS. Food-plants: Rorippa indica and Nasturtium officinale.

Natural enemy : Perilissus athaliae Uchida (Hymenoptera : Ichneumonidae) ex prepupae (Uchida, 1936), Dinorhynchus dybowskyi Jakovlev (Hemiptera : Pentatomidae) as a larval predator (Yasumatsu, 1965), Perilampus aeneus Rossi (Hymenoptera : Perilampidae) ex prepupae of A. r.rosae (Saringer, 1984), and Perilampus italicus F. ex prepupae of A. r.rosae (Boselli, 1932) according to Clausen, 1940.

5. Athalia kashmirensis Benson

[Japanese name: Inunofuguri-habachi]

A thalia cordata kashmirensis Benson, 1932, Ann. Mag.nat. Hist., 10(9): 187.

Athalia veronicae Takeuchi, 1949, Trans. Kansai ent. Soc.,14(2) : 49, nom. nud. (In Japanese.) ; 
Takeuchi, 1951, In Esaki et al. (eds.), Icon. Ins. Japon., p. 1343, Hokuryukan, Tokyo, nom. nud. (In Japanese.) ; Takeuchi, 1952, A Genetic Classification of the Japanese Tentkredinidae (Hymenoptera : Symphyta), p. 29, Kyoto, nom. nud.

Atkalia kashmirensis Benson, 1962, Bull.Brit.Mus (Nat. Hist.) Ent., 11(7): 367 ; Chu \& Wang, 1962, Acta zool.Sinica, 14(4): 510 (In Chinese.) ;Muche, 1982, Faun. A bk. St. Mus.Tierk., D resden, 9(9) : 115-116.

Biology : Okutani, 1967, Jap.J. appl. Ent. Zool., 11 : 93 (In Japanese.).

Adult (Figs. 2, G; 3, G;4, E ; 5, E ; 6, E)

Female

Coloration. Head black ; clypeus, labrum and basal $2 / 3$ mandibles whitish ; apical $1 / 3$ mandibles whitish brown ;palpi brownish yellow ; apices of antennae whitish brown. Thorax orange ; posterodistal margin of lateral lobe of mesoscutum, mesoposttergite, mesaxillae, mesopostnotum, metanotum, and metapostnotum black. Wings hyaline; tinged with gray; veins blackish brown. Legs orange ; tibiae except for ventral portion and tarsi except for basal portion of 1 st and 2nd tarsomeres black; tibial spur brown. Abdomen yellowish orange; proximal portion of 1st abdominal tergite yellowish brown; ovipositor sheath black.

Structure. Antennae 11-segmented (the apical two segments almost fused together) with only 9th segment broader than long; clypeal front margin on each side with an angle that separates off a lateral margin more than half as long as the diameter of an antennal sockets, the separated frontal margin almost straight or slightly sinuate; prelabium shorter than diameter of eye ; malar space $1 / 5$ as long as distance between antennal sockets. Tibial spurs long (hind inner spur about as long as tibial width) ; tarsal claws simple. Hypopygium excavated with a large triangular projection in the middle. Saw with prominent and sharp teeth; each tooth with 8-10 denticulations.

Pubescence pale throughout ; dense on head above ; very sparse on the shining clypeus ; bare on dorsal surfaces of 2-8 abdominal tergites.

Measurements (in mm) : Body length 5.1-7.2 (6.1) ; forewing length 5.4-7.6 (6.4) ; head width 1.5-2.0 (1.7) ; thorax width 1.5-2.0 (1.7) ; 3rd antennal segment length (0.5) ; 8th antenna1 segment (length $\times$ width) $(0.21 \times 0.19)$; 9 th antennal segment (length $\mathbf{x}$ width) $(0.18 \mathbf{x} 0.19)$; malar space $(0.06)$; distance between antennal sockets (0.23) ; eye (shortest diameter $\mathbf{x}$ longest diameter) (0.6 $\mathbf{x} 0.85)$; hind tibia1 inner spur length (0.2).

Male

Coloration. Similar to female except for ventral portion of scape whitish brown.

Structure. Similar to female, but eye strongly converging below and very short malar space. Genitalla (Fig. 6, E) : gonostylus short and somewhat curved inwardly, with a larger triangular ventral process ; cuspis moderately large and broad; digitus long and pointed ; interior swelling well developed, constructed basally.

Measurements (in mm) : Body length 4.8-5.8 (5.3) ; forewing length 4.7-5.7 (5.2); head width 1.3-1.9 (1.6) ; thorax width 1.3-1.7 (1.5) ; malar space (0.05) ; distance between antenna1 sockets (0.18) ; eye (shortest diameter $\mathbf{x}$ longest diameter) $(0.68 \times 0.91)$.

Mature Larva (5th instar larva) (Figs, 7, E ; 8, E)

Length 11-15 mm ( $\mathrm{n}=25$, avg. $=14.1 \mathrm{~mm})$; size of head capsule as in Table 1. Head black ; front with 22-23 setae ; lower portion of space between antennal sockets and mouth-parts whitish brown ; tips of mandibles brown. Body dark brown, mat, with grayish tint; thoracic wart-like processes weakly developed ; femoral projection sclerotized projection (in this species only).

$M$ aterial examined. Adults : 4499 and $83 \sigma^{\prime} \sigma^{\circ}$ from the following localities. JAPAN :Honshu- 
Niigata Pref. : Senami. Shizuoka Pref. : Kawazu. Tokyo Met. : Katsushika. Saitama Pref. : Shiki. Kyoto Pref. : Kyoto. Hyogo Pref. : Kobe. Shikoku-Kochi Pref. :Kochi. Kyushu-Fukuoka Pref. : Mt. Tachibanayama ; Hakozaki ; Mt. Homanzan; Mt. Hikosan; Mt. Wakasugiyama ; Mt. Joyama. Nagasaki Pref.: Tsushima. Is. Kagoshima Pref. : Okuchi. Larvae : 48 exs. from the following localities: FFH and FFT.

Distribution : Japan (Honshu, Shikoku, Kyushu), China, Kashimir and Assam (Fig. 19, G).

Host-Plant : Veronica persica Poir. [Ooinunofuguri) ; Veronica didyma Tenore var. lilacina (Hara) Yamazaki [Inunofuguri] and Veronica arvensis Linn. (Tachiinunofuguril (Okutani, 1967). All belong to the Scrophulariaceae.

LIFE CYCLE : Bivoltine; a reproductively active phase in spring and autumn, respectively, with aestivation in Japan (new record) (Fig. 15, D).

Chromosome number : Female, $2 \mathrm{n}=12$; male, $\mathrm{n}=6$. Locality : FFT and FFH (new record) (Fig. 11, D).

Electrophoretic pattern of larval hemolymph protein: As shown in Fig. 17, D. Locality: FFH and FFT. Food-plant : Veronica persica.

NAtural ENEmy : Unknown.

\section{Athalia yanoi Takeuchi, stat. nov.}

[Japanese name : Ezo-no-kawajisa-habachi (new name)]

Athalia liberta: Takeuchi (nec Klug), 1951, In Esaki et al. (eds.), Icon. Ins. Japon., p. 1343, Hokuryukan, Tokyo, (In Japanese.)

Athalia liberta yanoi Takeuchi, 1952, A Generic Classification of the Japanese Tenthredinidae (Hymenoptera:Symphyta), p. 29-30, Kyoto ; Benson, 1962, Bull.Brit.Mus. (Nat. Hist.) Ent., 11(7): 370 .

This is recognized as a full species, and treated as such in this paper. Takeuchi (1952) described yanoi as a subspecies of European A. liberta, which is known to occur from Europe to Asia. This was supported by Benson (1962). Comparing with the description of Chevin (1968), however, yanoi differs from liberta as follows : (1) clypeus angulated laterally (rounded in liberta), (2) hypopygium broadly and triangularly projected on the apical margin (notched in the middle in liberta), (3) saw with sharp teeth (blunt teeth in liberta), and (4) digitus of male genitalia narrowed apically (not narrowed in liberta). Moreover, Japanese yanoi feeds on Veronica (Scrophulariaceae), but the European liberta feeds on Sinapis and others (Cruciferae) (Benson, 1962 \& Vassilev, 1978).

\section{Female}

Adult (Figs. $1 ; 2, \mathrm{H} ; 3, \mathrm{H} ; 4, \mathrm{~F} ; 5, \mathrm{~F}, 6, \mathrm{~F}$ )

Coloration. Head black ; clypeus, labrum and basal 2/3 mandibles whitish ; apical 1/3 of mandibles whitish brown ; palpi yellowish brown, ventral portion of antennae brown. Thorax orange; dorsally black except for pronotum and tegulae. Wings hyaline ; tinged with dark brown; veins blackish brown. Legs orange; apical ringed portion of tibiae, apical $1 / 2$ ringed portion of lst, 2nd and 3rd tarsomeres, and 4th and 5th tarsomeres black. Abdomen yellowish orange ; proximal portion of 1 st abdominal tergite and ovipositor sheath black.

Structure. Antennae 10- segmented with no segment broader than long ; clypeal front margin on each side with an angle that separates off a larteral margin more than half as long as diameter of an antennal sockets, separated margin almost straight of slightly sinulate; prelabium shorter than diameter of eye ; malar space $1 / 3$ as long as distance between antennal sockets. Tibial spurs long 
(hind inner spur about as long as tibial width; tarsal claws simple. Hypopygium excavated with a large triangular projection in the middle. Saw with shallow teeth and 10-11 large denticulations to each tooth.

Pubescence pale throughout ; dense on head above ; very sparse on the shining clypeus ; bare on dorsal surfaces of 2-8 abdominal tergites.

Measurements (in mm) : Body length 5.8- 7.5 (6.6); forewing length 5.8-7.6 (6.7) ; head width 1.5-2.1 (1.8) ; thorax width 1.6-2.2 (1.9) ; 3rd antenna1 segment length $(0.59)$; 8th antenna1 segment (length $\mathbf{x}$ width) $(0.21 \times 0.18)$; 9 th antennal segment (length $\times$ width) $(0.19 \times 0.18)$; malar space $(0.04)$; distance between antennal sockets $(0.15)$; eye (shortest diameter $\mathbf{x}$ longest diameter) $(0.7 \mathbf{x} 0.91)$; hind tibia1 inner spur length (0.24).

Male

Coloration. Similar to female except for scape orange.

Structure. Similar to female, but eye strongly converging below, and very short malar space. Genitalia (Fig. 6, F) ; gonostylus short and somewhat curved inwardly, with a larger triangular ventral process ; cuspis moderately large and broad ; digitus long and pointed ; interior swelling well developed.

Measurement (in mm) : Body length 4.6 - 5.2 (4.9) ; forewing length 4.5- 5.1 (4.8) ; head width 1.2-1.4 (1.3) ; thorax width 1.1-1.3 (1.2) ; malar space (0.03) ; distance between antennal sockets (0.16) ; eye (shortest diameter $\mathbf{x}$ longest diameter) $(0.6$ x 0.95).

\section{Mature Larva (Figs. 7, F ; 8, F)}

Length: $11-16 \mathrm{~mm} . \quad(\mathrm{n}=16$, avg. $=14.8 \mathrm{~mm})$. Head black ; lower portion of space between antenna1 sockets and mouth-parts whitish brown with tips of madibles brown; front with 22-23 setae. Body dark brown with grayish tint ; thoracic wart-like processes weakly developed ; femoral projection membraneous.

Material examined. Adults : JAPAN : Hokkaido-Tokachi Prov. :1q, Shikaribetsu, 25. VII. 1939 (K. Takeuchi), Holotype, UOP ;19, Ashoro, 17. VI. 1967 (T. Naito), ELKU ; lb, Ashoro, 25. VI. 1980 (H. Takemoto), ELKU ;1 1 10’, Ashoro, 11. VI. 1984 (0. Tadauchi), ELKU ;191ð’, Ashoro, 11. VI. 1984

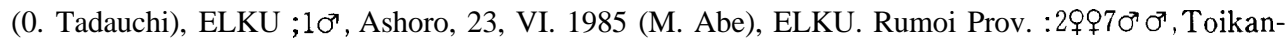
betsu, 27-29. VI. 1985 (M. Abe), ELKU. Kamikawa Prov. : 10', Soun-kyo, 12. VI. 1964 (S. Suzuki), EIHU ; 5\$12 $\sigma^{\Im}$, Asahidake-onsen, 10-11. VII. 1986 (T. Saigusa \& M. Abe), ELKU. Iburi Prov. : 1 ๆ, Tomakomai, 23. VI. 1959 (T. Kumata), EIHU. Ishikari Prov. : 10̛ , Sapporo, 8. VI. 1919 (S. Issiki), UOP ;1 9 , Mt. Teine, Sapporo, 1. VI. 1919 (S. Issiki), EIHU ;19, Mt. Moiwa, Sapporo, 2. VI. 1964 (K. Kushigemachi), EIHU ;181ð̛, Mt. Maruyama, 12. VI. 1934 (Y. Sugihata), EIHU. Honshu-Niigata

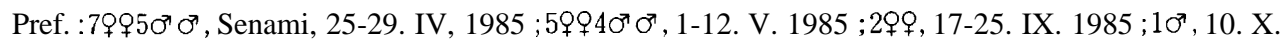
1985 (K. Baba), ELKU. Kanagawa Pref. : Hakone, 21. VI. 1937 (K. Takeuchi), UOP. SAGHALIN : 1 ㅇ, Tarandomari, 25-27. VII. 1934 (C. Watanabe \& T. Inoue), EIHU ; 19, Konuma, 6-8. VII. 1933 (T.

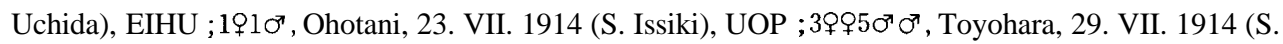

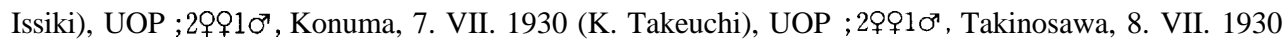
(K. Takeuchi), UOP. Larvae: 28 exs. from HKA and HIT.

Distribution : Japan (Hokkaido \& Honshu) and Sakhalin (Fig. 19, I).

Host-Plant: Veronica americana (Rafin.) Schwein. 〔Ezonokawajisa) in HIT and HKA (new records). This species belongs to the Scrophulariaceae.

LIFE CYCLE: Bivoltine ; a reproductively active phase in spring and autumn, respectively, with aestivation in Niigata Pref. (new record).

ELECTROPHORETIC PATTERN of LARVAL HEMOLYMPH PROTEIN : As shown in Fig. 17, E. Locality : HKA. Food-plant : Veronica americana. 
KARYOTYPE AND NATURAL ENEMY : Unknown.

7. Athalia scutellariae Cameron

[Japanese name : Tatsunamiso-habachi (new name)]

Athalia scutellariae Cameron, 1880, Ent. mon. Mag., $17: 66$; Benson, 1952, Handbks. Ident.Brit. Ins., London, 6(2):82 ; Lorenz \& Kraus, 1957, Abh. Larvalsyst.Insekt., $1: 89$; Zombori, 1978, Actazool. Hung., 24(3 \& 4): 228-231.

Athalia fammula Zhelochovtsev, 1927, Ent. Mitt., $16: 82$.

Dentathalia scutellariae : Benson, 1931, Ent. mon.Mag., 67: 111.

Dentathalia galericulatae Kontuniemi, 1951, Acta. ent. fenn., 9 : 44.

Athalia scutellariae scutellariae : Benson, 1954, Bull.Brit. M us. (Nat. Hist.) Ent., 3(7) : 273 ; Zombori, 1972, Acta zool. Acad. Sci. hung., 24(3\& 4) : 435-447.

Athalia scutellariae flammula: Benson, 1954, Bull. Brit.Mus. (Nat. Hist.) Ent., 3(7) : 273 ; Zombori, 1972, Acta zool. Acad. Sci. hung., 24(3\& 4) : 435-447.

Benson (1954) regarded A. flammula Zhelochovtsev as a subspecies of A. scutellariae, but I am not sure for the status of flammula. I recognized A. scutellariae from Japan (Hokkaido) for the first time.

Female

Adults (Fig. 2, I ; 3, I ; 4, G \& I ; 5, G)

Coloration : Head black ; clypeus, labrum, and basal $2 / 3$ of mandibles brownish white ; apical $1 / 3$ of mandibles and antennae ventrally reddish brown ; antennae dorsally brown. Thorax orange ; dorsum dark brown-reddish brown except for pronotum and tegulae. Wings hyaline ; tinged with dark brown ; veins brownish black. Legs orange ; apical $1 / 3$ ringed portions of tibiae, apical $1 / 2$ ringed portions of 1st-4th tarsomeres, and 5th tarsomere black. Abdomen yellowish orange ; proximal portions of 1 st abdominal tergite black.

Structure. Antennae 11-segmented with 8th, 9th, and 10th segments broader than long ; clypeus slightly sinuate in front, not rounded, not angled laterally ; prelabium shorter than diameter of eye ; malar space as long as distance between antennal sockets. Tibial spurs long, inner hind tibial spur about as long as tibial width ; tarsal claws with inner tooth in addition to end tooth ; hypopygium scarcely emarginate behind ; saw with less prominent teeth.

Measurements (in mm). Body length (4.9) ; forewing length (4.8); head width (1.4); thorax width (1.5) ; 3rd antenna1 segment length (0.45) ; 8th antenna1 segment (Length Xwidth) (0.11 x 0.13) ; 9th antennal segment (length $\mathrm{X}$ width) $(0.11 \times 0.13)$; malar space $(0.09)$; distance between antennal sockets $(0.1)$; eye (shortest diameter $x$ longest diameter) $(0.48 \mathrm{X} 0.75)$; hind tibial inner spur length $(0.18)$.

Material examined. 19, Odaito, Nemuro Prov., Hokkaido, 1. VIII. 1967, H. Shima leg., ELKU; 1 १, Odaito, 1. VIII. 1967, A. Nakanishi leg., ELKU ; 19, Odaito, 1. VIII. 1967, T. Saigusa leg., ELKU.

DistRiBution : Japan (Odaito, Nemuro Prov., Hokkaido) ; Europe; West Asia (Fergan Mountain, Kirghiz) ; East Siberia (Fig. 19, J).

Larva, host-plants, life-cycle, karyotype, and electrophoretic pattern of hemolymph protein in this species of Japan are unknown. The larva, however, was described by Lorenz \& Kraus (1954). The host-plants by Benson (1962) and the life-cycle by Benson (1931a) were reported as follows.

Host-PLANTS :Scutellaria gallericulata L. and Scutellaria minor L. (Benson, 1962). Both species belong to the Labiatae.

Life-cycle : Bivoltine; an active phase in spring and autumn, respectively with aestivation in England (Benson, 1931a). 


\section{References}

Anderé, E., 1879. Species des Hyménoptères d'Europe et d'Algérie, I. 642 pp. Beaune, Côte-d'Or.

Atarashi, N., 1953. On the ovipositing behavior and the egg-development of Athalia rosae japonensis. $\bar{O} \bar{y}-$ Konty $\bar{u}, \mathbf{9}(1): 23-29$. (In Japanese.)

Baba, K. \& I. Togashi, 1985. Seasonal fluctuation of sawflies occurring in Senami district, Murakami-shi, Niigata Prefecture. Bull. Essa ent. Soc. 60 :3-8. (In Japanese.)

Benson, R. B., 1931a. Notes on the habits and the occurrence of Athalia species in Britain. Ent. mon. Mug., 67: 109-115.

- 1931b. Notes on the British sawflies of the genus Athalia (Hymenoptera : Tenthredinidae) with the description of a new species. Ibid., $67:$ 108-115.

- 1932a. Sawfly notes.-II. Parallel variation in Athalia lugens Kl. and Athalia cordata Lep. Ann. Mag.nat. Hist., 10(9): 183-188.

- 1932b. Sawfly notes.-III. On some species of Athalia from Central Asia and from the Mount Everest Region (Hymenoptera : Symphyta). Ibid., 10(9): 189.

- 1952. Hymenoptera, Symphyta, Tenthredinidae. Handbooks for the Identification of the British Insects, 6, Part 2(b), 137 pp. London.

- 1954. Some sawflies of the European Alps and the Mediterranean region (Hymenoptera : Symphyta). Bull. Brit. Mus. (Nat. Hist.) Ent., 3(7) : 269-295.

—, 1962. A revision of the Athaliini (Hymenoptera : Tenthredinidae). Bull. Brit. Mus. (Nat. Hist.) Ent., 11(7): 335-382.

Cameron, P., 1876. Descriptions of new genera and species of Tenthredinidae and Siricidae, chiefly from the East Indies, in the collection of the British Museum. Trans. ent. Soc. Lond. 3(10) : 459471.

—, 1877. Descriptions of new genera and species of East India Tenthredinidae. Trans. ent. Soc. Lond., 2(6) : 87-92.

—, 1880. Notes on Tenthredinidae. Ent. mon. Mug., $17: 66-67$.

- 1904. Description of a new species of Athalia (Tenthredinidae) from India. Z. syst. Hym. Dipt., $1(6): 108$.

Chevin, H., 1969. Les espèces européennes du genre Athalia (Hym. Tenthredinidae). Ann. Soc. ent. Fr. (N. S.), 5(4) : 825-836.

Chikaoka, I. et al., 1968. [Insect pests on cruciferous plants.] In Nomura (eds.), Genshoku-byogaichushindan- boujo-hen, 3. 84 pp. No-san-gyo-son-bunka-kyokai, Tokyo. (In Japanese.)

Chu, H. F. \& L. Y. Wang, 1962. A synoptical study on the Chinese sawflies of the subfamily Athaliinae (Hymenoptera : Tenthredinidae). Acta zool. Sinica, 14(4) : 505-514. (In Chinese.)

$-\&-$, 1963. Studies on the Chinese cabbage sawflies with special reference to geographical distribution. Acta ent. Sinica, 12(1) : 93-97. (In Chinese.)

Clausen, C. P., 1940. Entomophagous Insects. 688 pp. McGraw-Hill, New York \& London.

Davis, B. J., 1964. Disc electrophoresis. II. Method and application to human serum proteins. Ann. N. Y. Acad. Sci., 121: 404-427.

Dhillon, S., 1966. Morphology and biology of Athalia proxima Klug (Tenthredinidae, Hymenoptera). Alig. Musl. Univ. Publ.(Zool. Ser.) Indian Ins. Typ., $7:$ 1-144.

Fabricius, J., 1793. Entom. system. II : 110.

Forsius, R., 1925. J. B. Corporaal's Tenthredinoiden-Ausbeute aus Sumatra. Notul. ent. Helsingf., 5 : 91-92.

—, 1927. Tenthredinoiden aus China. Arkiv Zool., 19A(10): 6-7.

_ 1928 . Über die von Wuorentaus in Kamtschatka gesammelten Tenthredinoiden. Notul. ent. 
Helsingf., $8: 46$.

—, 1934. Über einige Tenthredinoiden Javas. Rev. suisse Zool., 41(4) : 106.

Hussain, T. \& N.Chatha, 1982. Mating behaviour and oviposition of Athalia proxima Klug (Hymenoptera : Tenthredinidae). Pakistan J.Zool., 14(1): 117-118.

Imai, H. T., R. H. Crozier, \& R. W. Taylor, 1977. Karyotype evolution in Australian ants. Chromosoma (Berl.), 59 : 341-393.

Kitano, H., 1950. [Relationship between the place of cocoon and soil moisture in Athalia japonica (Klug).], Shin Konchī, 3(4) : 39-40. (In Japanese.)

Klug, F., 1816 Die Blattwespen nach ihren Gattungen und Arten zusammengestellt. Mag. Ges. naturf. Fr., Berlin, $7: 127-131$.

Kontuniemi, T., 1951. Zur Kenntnis des Lebenszyklus der Sägewespen (Hymenoptera, Symphyta) in Finland. Acta ent. fenn., $9: 38-47$.

Lorenz, H. \& M. Kraus, 1957. Die Larvalsystematik der Blattwespen (Tenthredinoides und Megalodontoidea). 339 pp. Berlin.

Marlatt, M. S., 1899. Japanese Hymenoptera of the family Tenthredinidae. Proc.U.S. nat. Mus., 21: $493-506$.

Masaki, S., 1980. Summer diapause. Ann. Rev. Entomol., 25 : l-25.

Matsuda, R., 1976. Morphology and Evolution of the Insect Abdomen. 534 pp. Pergamon, Oxford et al.

Matsumura, S., 1912. Thousand Insects of Japan, 4. 147 pp. Keisei-sha, Tokyo. (In Japanese.)

—— \& T. Uchida, 1926. Die Hymenopteren-Fauna von den Riukiu-Inseln. Ins. Mats., 1: 70.

Maxwell-Lefroy, H., 1908. The mustard sawfly (Athalia proxima Klug). Mem. Dep. Agric. India Ent., l(6) : 357-370.

Muche, W. H., 1982. Eine Tenthredinidae-Sammelausbeute aus Indien (Hymenoptera: Symphyta). Faun. Abh. St. Mus. Tierk. Dresden, 9(9):115-116.

Naito, T., 1982. Chromosome number differentiation in sawflies and its systematic implication (Hymenoptera, Tenthredinidae). Konty $\widehat{u}$, Tokyo, 50(4) : 569-587.

Narutomi, N., 1931. [Biology of Athalia spp.], Jap. J.appl.Zool., 3 : 190-193. (In Japanese.)

Oda, F., 1936. Engei-gaichu-zu-hen. 334 pp. Meibun-do, Tokyo. (In Japanese.)

Ohwi, J., 1978. Flora of Japan. Rev. Ed. 1584 pp. Shibun-do, Tokyo. (In Japanese.)

Okuno, T. et al., 1978. Diseases and Pests of Flowers and Vegetables in Colour. 366 pp. Hoikusha, Osaka. (In Japanese.)

Okutani, T., 1954. [Rearing experiments in sawflies.] Shin Konchū, 7(6):37-38. (In Japanese.)

--, 1959. Symphyta. In Kawada et al. (eds.), Illustrated Insect Larvae of Japan :548-582. Hokuryukan, Tokyo. (In Japanese.)

—, 1967. Food-plants of Japanese symphyta (II). Jap. J.appl.Ent.Zool. 11: 90-99. (In Japanese.)

- 1977. Symphyta. In Ito et al. (eds.), Coloured Illustrations of the Insects of Japan, 2: 285-294. Hoikusha, Osaka. (In Japanese.)

Onuki, S. \& S. Nakagawa, 1902. Noji-shiken-jo-hokoku, 23: 47-52. (In Japanese.)

Richards, 0. W., 1956. Hymenoptera. Introduction and key to Families. Handbooks for the Identification of the British Insects, 6, Part 1, 100 pp. London.

Rohwer, S. A., 1910. Japanese sawflies in the collection of the United State National Museum. Proc. U.S.. nat. Mus., $39: 99-120$.

Saringer, G., 1984. Relationship between the photoperiod and the diapause of endoparasites of Athalia rosae L. Acta Agronomiae Acad. Sci. Hung., 33: 57-58.

Smith, E. L., 1969a. Evolutionary morphology of external insect genitalia. 1. Origins and relationships to other appendages. Ann. ent. Soc. Amer., 62: 1051-1079. 
- 1969b. Evolutionary morphology of external insect genitalia. 2. Hymenoptera. Ibid., 63 : l-27. Sonan, H. \& K. Shibata, 1928. Ecological studies of Athalia japonica (Klug). Trans. nat. Hist. Soc. Formosa, 18(94) : 49-64. (In Japanese.)

Takahashi, Y ., 1948. Nogyo-gaichu-hen. 398 pp. Youken-do, Tokyo. (In Japanese.)

Takeuchi, K., 1919. List of Japanese sawflies. Ins. World, 23(261): 182-188. (In Japanese.)

- 1949. A list of the food-plants of Japanese sawflies. Trans. Kansai ent. Soc., 14(2): 47-50.

- 1950. Symphyta. In Esaki et al. (eds.), Iconographia Insectorum Japonicorum : 1329-1361. Hokuryukan, Tokyo. (In Japanese.)

- 1952. A Genetic Classification of the Japanese Tenthredinidae (Hymenoptera : Symphyta), 88 pp. Kyoto.

- 1955. Symphyta. In Esaki \& Takeuchi (eds.), Coloured Illustrations of the Insects of Japan, 2: 112-128. Hoikusha, Osaka. (In Japanese.)

Togashi, I., 1965, Symphyta. In Yasumatsu et al. (eds.), Iconographia Insectorum Japonicorum, Colore Natutali Edita, $3: 243-254$. Hokuryukan, Tokyo. (In Japanese.)

— 1972. A note on the seasonal occurrence of sawflies (Hym. Symphyta) on Mt. Hiko, Kyushu. Mushi, Fukuoka, 46: 129-135.

Tsutsui, K., 1960. Genshoku-seitai-sakumotsu-gaichu-zufu. 438 pp. Youkendo, Tokyo. (In Japanese.)

Uchida, T., 1936. Drei neue Gattungen sowie acht neue und fuenf unbeschriebene Arten der Ichneumoniden aus Japan. Ins. M ats., 10(3): 111-121.

Uesumi, Y ., 1976. In Kishi (ed.), Yasai-no-byo-gaichu : 479-481. Zenkoku-noson-kyoiku-kyokai, Tokyo. (In Japanese.)

Vassilev, I. B., 1978. Hymenoptera, Symphyta. Fauna Bulgaria, 8. 179 pp. (In Bulgarian.)

Yanata, H., 1906. Saishin-sakumotsu-gaichu-hen. 348 pp. Bunbu-do, Tokyo. (In Japanese.)

Yano, M., 1920. [Taxonomy of the genus Athalia of Japan.] J. Plant Prot., 7(10) : 549-555. (In Japanese.)

- 1932 . Symphyta. In Uchida et al. (eds.), Iconographia Insectorum Japonicorum : 428-476. Hokuryukan, Tokyo. (In Japanese.)

Yago, M., 1929. Engei-gaichu-danpen (III). J. Plant Prot., 16(12): 737-738. (In Japanese.)

Yasumatsu, K. \& C. Watanabe, 1965. Host parasite-predator catalogue. A Tentative Catalogue of Insect Natural Enemies of Injurious Insects in Japan, 2. 116 pp. ELKU, Fukuoka.

Yuasa, H., 1922. A classification of the larvae of the Tenthredinidae. Illinois biol. Monogr., 7(4):1172.

Yuasa, H. \& A. Kawada, 1952. Nosakumotsu-gaichu-shin-setsu. 491 pp. Asakura, Tokyo. (In Japanese.)

Zhelochovtsev, A., 1927. Neue Tenthredinoidea aus Asien (Hym.) Ent. Mitt., 16 : 81-83.

Zombori, L., 1972. Symphyta (Hymenoptera) from Mongolia. II. Acta zool. Acad. Sci. hung., 18(3 \& 4) : 435-447.

- 197. 1. The symphyta of the Dodera collection. 1. Description of six new taxa and notes on synonymy (Hymenoptera). Acta zool. Hung., 24(3 \& 4) : 228-231. 